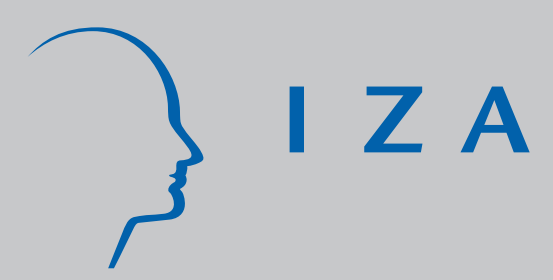

IZA DP No. 5846

Parental Job Loss and Children's Health: Ten Years after the Massive Layoff of the SOEs' Workers in China

Hong Liu

Zhong Zhao

July 2011 


\title{
Parental Job Loss and Children's Health: Ten Years after the Massive Layoff of the SOEs' Workers in China
}

\author{
Hong Liu \\ Central University of Finance and Economics \\ Zhong Zhao \\ Renmin University of China \\ and IZA
}

Discussion Paper No. 5846

July 2011

IZA

P.O. Box 7240

53072 Bonn

Germany

Phone: +49-228-3894-0

Fax: +49-228-3894-180

E-mail: iza@iza.org

\begin{abstract}
Any opinions expressed here are those of the author(s) and not those of IZA. Research published in this series may include views on policy, but the institute itself takes no institutional policy positions.

The Institute for the Study of Labor (IZA) in Bonn is a local and virtual international research center and a place of communication between science, politics and business. IZA is an independent nonprofit organization supported by Deutsche Post Foundation. The center is associated with the University of Bonn and offers a stimulating research environment through its international network, workshops and conferences, data service, project support, research visits and doctoral program. IZA engages in (i) original and internationally competitive research in all fields of labor economics, (ii) development of policy concepts, and (iii) dissemination of research results and concepts to the interested public.
\end{abstract}

IZA Discussion Papers often represent preliminary work and are circulated to encourage discussion. Citation of such a paper should account for its provisional character. A revised version may be available directly from the author. 


\section{ABSTRACT}

\section{Parental Job Loss and Children's Health: Ten Years after the Massive Layoff of the SOEs' Workers in China*}

Beginning in the mid 1990s, China sped up its urban labor market reform and drastically restructured its state-owned enterprises (SOEs), which resulted in massive layoff of the SOEs' workers and a high unemployment rate. In this paper, we investigate the impact of the parents' job loss on the health of their children, using six waves of the China Health and Nutrition Survey covering the period from 1991 to 2006. We find that paternal job loss has a significant negative effect on children's health, whilst maternal job loss has no significant effect. The rationale behind the findings is that the income loss resulting from maternal job loss is much smaller; at the same time, the unemployed mothers are likely to increase the time they devote to care of their children, and this may alleviate the negative effect resulting from maternal job loss. Our findings are robust to various specifications.

JEL Classification: $\quad$ I12, J63, N35, J13

Keywords: $\quad$ children's health, job loss, Grossman's model, China

Corresponding author:

Zhong Zhao

School of Labor and Human Resources

Renmin University of China

59 Zhongguancun Ave

Beijing 100872

China

E-mail: mr.zhong.zhao@gmail.com

\footnotetext{
* We would like to thank Gary Becker, Jim Heckman, Wanchuan Lin, Minquan Liu, Yaohui Zhao, and participants of the 1st Chicago-Renmin Symposium on Labor and Family Economics; the International Conference on Economic Stress, Human Capital, and Families in Asia: Research and Policy Challenges; the 2nd CIER/IZA Annual Workshop: Research in Labor Economics; the Annual Conference of the Chinese Economist Society; and a seminar at Peking University for their helpful comments.
} 


\section{Introduction}

Children's health is widely regarded as an important kind of human capital in both developing and developed countries, which has significant implications for a host of important outcomes, such as educational performance and long-term labor market outcomes in later life (Currie and Moretti, 2007; Cunha, Heckman, and Schennach, 2010; Chen and Zhou, 2007). A large body of literature has been devoted to understanding the relationship between family socioeconomic characteristics and children's health (Case, Lubotsky, and Paxson, 2002; Currie and Stabile, 2001). The consensus is that family social status and children's health are positively correlated. Financial well-being in early life has profound long-term consequences (van den Berg, Lindeboom, and Portrait, 2006; Maccini and Yang, 2009).

As a key indicator of family economic security, parental employment affects substantially the family time and income resources invested in child health (Gennetian et al., 2010). However, the theory of parental employment and children's health is ambiguous. On the one hand, parental employment brings more financial resources and hence improves the health of the children; on the other hand, employment is likely to reduce the parental time with the children, which may have an adverse effect on their health. The empirical evidence on the linkage between maternal employment and health outcomes of the children is also mixed, variously suggesting adverse effect, insignificant effect, and small positive effect. For example, empirical studies have found that limited market work benefits children in low-income families (Ruhm, 2008); that nonemployment resulting from maternity leave has no significant effect on 
children's health (Baker and Milligan, 2008); and that maternal employment has an adverse health effect on low-income young children (Gennetian et al., 2010) and school-age children (Morrill, 2011), and increases a child's likelihood of becoming overweight (Cawley and Liu, 2007; Liu et al., 2009). However, most of those empirical studies derive mainly from developed countries and refer to maternal employment. Little is known about whether the results can be replicated in developing countries, such as China. And few studies deal with paternal employment or attempt to differentiate the effect of maternal (un)employment from the effect of paternal (un)employment.

Though China started to reform its Soviet-style economic system in 1978, urban labor market reform only began in the mid 1980s. From the mid 1980s to the mid 1990s, the urban labor market reform proceeded gradually, and mainly focused on improving managerial and worker incentives with the introduction of a bonus system and piece-rate wages (Knight and Song, 2003; Dong and Xu, 2009). Life-term employment basically remained unchanged. In the mid 1990s, China initiated a profound reform of the state-owned enterprises (SOEs), and started to massively lay off redundant state workers (Appleton, Song, and Xia, 2005). From 1998 to 2005, more than 35 million workers got laid off, and the total number of workers in the state sector (including SOEs, urban collectives, and cooperative enterprises) went down from 144 million in 1995 to 78 million in 2004 (World Bank, 2007). This reform resulted in considerable financial hardship for the laid-off families, and inevitably affected the well-being of the children in those families. 
In this paper, we aim at investigating the impact of parents' job loss on the health outcomes of their children in China ${ }^{1}$, using six waves of longitudinal data from the China Health and Nutrition Survey (CHNS) 1991-2006, which covers China's urban-labor-market restructuring period. The contribution of our work has four parts.

First, the SOE retrenchment is an important social phenomenon in contemporary China, creating considerable financial hardship, income insecurity, and uncertainty for many Chinese families. To our knowledge, however, no study has been done to examine the impact of this unfortunate and significant event on the children's health.

Second, in contrast with previous studies, which are mainly on the effect of maternal employment on children's health, in this paper we study the impact of both paternal job loss and maternal job loss on children's health, and compare the different roles of father and mother in child health production. Besides, most of the literature is on developed countries, and our study contributes to the literature on child health in development economics.

Third, given the rich information we have, we not only examine the heterogeneous effects of parental job loss for different demographic groups, but also investigate several potential linkages, such as the income effect, parental time allocation, and risky behavior of family members, between parental job loss and children's health.

Fourth, previous studies on parental unemployment and children's health often

\footnotetext{
${ }^{1}$ Children's education is another important outcome variable; however, the data set we used here has much rich information on health, but spotty information on education outcome.
} 
suffer from endogeneity; e.g., the status of unemployment is often endogenous. In our case, the job loss is mainly caused by the SOE retrenchment, which was an exogenous shock to individual families. This alleviates the selection-bias problem. Our approach is similar to the one adopted by Oreopoulos, Page, and Stevens (2008), who identify the effect of intergenerational income transmission using exogenous firm closures to avoid complications of possible endogenous choice on employment status.

The rest of the paper is organized as follows: Section 2 outlines the theory and channels that link parental job loss and children's health. Section 3 describes the data set, health measurements, sample selection, and descriptive statistics. Section 4 outlines our econometric framework. Section 5 presents the empirical results, including the main results, heterogeneous effects on various groups, and a robustness check for our main results. In that section, we also discuss empirical evidence on several channels that link parental job loss to children's health. Section 6 concludes the paper.

\section{Theory and Channels}

Economists have considered health as human capital for a long time (Mushkin, 1962; Becker, 1964; Fuchs, 1966). Building on human capital theory, Grossman (1972) formulated a formal model to analyze health capital; also see Grossman (2000). The conceptual contribution of Grossman (1972) is to treat health as capital. The health status reflects the stock of health capital. Two key factors - the investment factor (investing in health) and the depreciation factor (depreciation of health capital) determine the stock of health, and hence the health status. 
However, unlike market goods or ordinary investments, which can be bought from a store or made in a stock market, it is impossible to purchase a unit of health in a market. Conceptually, since the work of Grossman (1972), economists have modeled health as an output of household production according to Becker (1965). In this model, households "combine time and market goods to produce more basic commodities that directly enter their utility functions," as stated in Becker (1965).

Though Grossman's model is based on working adults, it is a powerful tool to understand and to analyze the health of other age groups as well. Following the argument in Grossman's $(1972 ;$ 2000) human capital model, child health can be produced by families using health inputs. Parents maximize their intertemporal utility function, depending on their own consumption and the well-being of their children, subject to the child health production function, income budget, and time constraints. Children start with a health endowment that depreciates over time in the absence of health inputs. As a kind of capital, health can be produced by inputs, including health-related goods and services purchased in the market such as health care and diet, and parents' time-intensive activities such as preparing healthy meals and cleaning house. Childhood is a period for accumulating health capital. In this period, the investment factor dominates the depreciation factor. The intertemporal nature of parents' utility function highlights the importance of health investments in both the short and the long run.

The child's health as well as health inputs is derived from the maximization of the parents' utility function. The health functions depend on family income, input 
prices, efficiency in health production technology, heritable health endowments, and time preference. Accordingly, there may be three channels through which parental job loss affects children's health. ${ }^{2}$ First, job loss may result in income loss, hence change the monetary budget constraint, and affect the inputs of the child health production function, such as nutrition intake and other market goods (e.g., health care services) used to produce health. This is the well-established income-health gradient (Case, Lubotsky, and Paxson, 2002; Currie and Stabile, 2001).

The second channel is parental time allocation. After job loss, the parents may spend more time on home production, and thus provide better supervision and care of their children. For example, Baker and Milligan (2008) find that an increase in maternity leave increases the duration of breastfeeding significantly. These two channels operate in opposite directions, leading to an ambiguous net effect of parental job loss. In addition, given the different roles of father and mother in home production and their different preferences, the two channels may work differently, depending on whether the lost job is that of the mother or the father.

Thirdly, when the parents become unemployed, they may change their lifestyle and engage in risky behaviors such as smoking, due to psychosocial stress (Vogli and Santinello, 2005; Montgomery et al., 1998). Parents' risky behavior may

\footnotetext{
2 In most developed countries, children may receive health insurance coverage from their parents' employment. Thus there may be one more channel linking parental job loss and child health. However, in China the urban health insurance system mainly consisted of the labor insurance scheme (LIS) and the government employee insurance scheme (GIS) before 1998, and children were treated as dependents eligible for partial coverage (Liu, 2002). In 1998, the government launched a health reform in urban china, aiming at merging the dual system of GIS and LIS into a new insurance scheme known as the Urban Employee Basic Health Insurance Scheme (BHIS) (Xu et al., 2007). In most areas, dependent children of the insured, who used to be partially covered by the LIS, were excluded from the new health insurance system. Thus in this paper we do not consider the channel of health insurance.
} 
change the technology of the children's health production function, and make the production of health less efficient.

Therefore, theoretically we hypothesize that parental job loss has an ambiguous effect on child health status, and the effect of maternal job loss may differ from the effect of paternal job loss.

\section{Data}

\section{The China Health and Nutrition Survey}

The data used in this study is the China Health and Nutrition Survey (CHNS). The CHNS is a longitudinal survey providing rich information to study social and economic changes in both urban and rural China, and their effects on the economic, demographic, health, and nutritional status of the Chinese population. The CHNS utilizes a multistage, random cluster-sampling scheme and has collected eight waves of data in 1989, 1991, 1993, 1997, 2000, 2004, 2006, and 2009. The survey area covers 9 out of 31 provinces in China, including coastal, middle, northeastern, and western provinces. The nine provinces host approximately 45 percent of China's total population and vary widely regarding geography, economic development, public resources, and health indicators. In each province, both big cities and small cities are sampled. The CHNS also includes cities from different income levels, and surveys both rural and urban residents. Currently there are about 4,400 households with 19,000 individuals in the survey. Among these respondents, about 30\% are from urban areas and $70 \%$ are from rural areas. 


\section{Measures of Children's Health}

Health has many dimensions and is difficult to measure (Cutler and Richardson, 1997; Field and Gold, 1998). Following the literature studying child health in developing countries (Strauss and Thomas, 1998; Chen and Li, 2009), we use anthropometric measures. ${ }^{3}$ Using children in urban China as the reference population, we construct the height-for-age $z$-score (HAZ) and the weight-for-age $z$-score (WAZ) as our measures of health outcome. ${ }^{4}$ More specifically, the $z$-scores are calculated as the difference between actual height (weight) and median height (weight) divided by the standard deviation in the reference population (children of the same age and gender).

\section{Samples and Definitions of Job Loss Status}

In this paper, we only use the sample from urban areas and from waves 1991 to 2006, since the reform of SOEs mainly occurred in urban China and started in the mid 1990s. ${ }^{5}$

As shown in Table 1, we construct two samples. Sample 1 includes parents with working history in the public institutions, SOEs, or collectively owned firms, along with their children. These institutions and firms were the focal point of the Chinese urban labor market reform, and workers in these places were the primary target for layoffs during the ownership restructuring period. Sample 2 includes parents

\footnotetext{
${ }^{3}$ On the other hand, studies on children's health in developed countries often use self-reported status, e.g., Gennetian et al. (2010).

${ }^{4}$ The information on the body development of Chinese urban children is from China Health Statistics (2004 and 2005).

${ }^{5}$ The eighth wave of the CHNS data was collected in 2009 and is partly available now, but its data on child height and weight have not been released yet. For the purpose of our study, we are not able to use CHNS 2009.
} 
with any working history and their children.

----Table 1-----

The CHNS survey does not have direct information on whether a person is laid off or not from public institutions, SOEs, or collectively owned firms. We construct the variable jobloss using employment histories from different waves of the survey. It has to be admitted that this construction of jobloss does not exactly measure laid-off status and might induce measurement error. ${ }^{6}$ We experiment with two different definitions of unemployment status as a robustness check. Definition 1 is that anyone changing work status from full-time to part-time, or from working to unemployed, is counted in jobloss, i.e., we do not count a person changing his/her work status from working to being out of the labor market as contributing to jobloss. Definition 2 is that any one changing work status from full-time to part-time, or from work to unemployed, or from work to being out of the labor market is counted in jobloss. This captures the fact that there were many discouraged workers during the SOE retrenchment period.

Combining the two samples and the two definitions, as summarized in Table 1, we have four different ways of defining lost-job status. Sample 1 (i.e., only considering the parents employed by the SOEs, collective enterprises, or public institutions), along with definition 1, is the main measure of lost-job status used in this paper. This definition is the closest one to the definition of the SOE layoff. In the robustness check, we experiment with the other three measures.

\footnotetext{
${ }^{6}$ Since the famous tour of Deng Xiaoping in the southern China, in 1992, a large portion of employees in the SOEs and public institutes have switched to private sector. We cannot identify them in our data, and do not classify them as lost-job.
} 
Using the main measure of job loss and the CHNS 1991 to 2006, we start with 4,703 observations of children aged 0 to 17.99 living in urban areas. We exclude 327 observations with missing key information on the parents, and 493 observations with missing or extreme values of height-for-age and weight-for-age $z$-scores (below -10 or above $10 ; 11$ respondents). We then restrict the sample to those with parental job-loss status information (excluding 1,754), and finally obtain the study sample of 2,129 .

\section{Other Key Variables and Descriptive Statistics}

Appendix Table A1 summarizes key dependent variables and independent variables that we are using in the paper. The information is very rich, including characteristics of the child, father's and mother's socioeconomic status, nutrition intake of the children, parental time allocation, smoking behavior, education and health information about the parents, etc.

In our sample, about $6 \%$ of mothers and $10 \%$ of fathers have experienced job loss. Children in the lost-job families have less protein, calorie, and carbohydrate intakes, and are younger (9.65 vs. 10.82 years). Without controlling for other variables, there is no significant difference in height-for-age $z$-score and weight-for-age $z$-score between children in lost-job families and in non-lost-job families.

Parents in the lost-job families are about 2 years younger. However, the education level, height, weight, and body mass index (BMI) of the parents are quite similar in lost-job and in non-lost-job families.

Our empirical model also controls for other covariates affecting child health 
status. Health insurance coverage is a binary indicator of whether the child has health insurance at the survey time. Individual demographic variables include child age, gender, a Han ethnicity (the largest ethnicity group in China) dummy, student status, household income, gender of household head, and number of children and number of adults in the household. We also control for parents' demographic and socioeconomic characteristics if applicable, including parents' age, height, BMI, education, missing mother, and missing father. In addition, five wave indicators are included to reflect the time trend of child health status.

One objective of this study is to test several channels that link parental job loss and child health outcomes. More specifically, we examine the impact of paternal job loss or maternal job loss on the change of household income, child average daily nutrient intake, child health care use, parental time allocation, and smoking behavior of family members.

Household income change is measured by the difference of total household income or per capita household income at time $t$ and time $t-1$. In our sample, the total gross household income as well as per capita income of a lost-job family is actually higher, but it is worth noting that after controlling for other variables, such as characteristics of the parents, the laid-off family indeed suffers from a negative income shock; see Table 7.

Child average daily nutrition intake includes three measures: protein intake (in grams), fat intake (in grams), calorie intake (in kilocalories), and carbohydrate intake (in grams). To make age- and gender-matched comparisons, these three nutrition 
intake measures are also standardized using sample mean and sample standard deviation for each age and gender group ${ }^{7}$. These two sets of variables reflect the income effect through the budget constraint of the home production function. ${ }^{8}$

Child health care utilization is measured by two dichotomous variables indicating whether the child (under age 12) received any immunizations during the previous year, and whether the child received any preventive health service, such as health examination, eye examination, or blood test, during the previous 4 weeks. It is worth noting that most child immunization is free in China, so child immunization behavior is likely to reflect parental time allocation rather than the budget constraint of the household. These two sets of variables are expected to indicate the channel of parental time allocation in the process of child health production.

We also directly examine three binary variables related to parental time allocation; they are whether the father or mother took care of children aged 6 and younger, bought food, or cooked food for the household during the previous 4 weeks.

Information on smoking behavior includes parents' smoking, measured by an indicator for whether the mother or the father smoked cigarettes at the survey time, and adolescent smoking initiation, measured by an indicator for whether a child (age 12 or older) started smoking between time $t^{-1}$ and time $t$. This set of smoking indicators is used to show the third channel relevant to the technology of children's health production function.

\footnotetext{
${ }^{7}$ We also used the nonstandardized measures of dietary intake as the dependent variables, and the results are almost the same.

${ }^{8}$ Studies in public health, e.g., Alaimo (2001), also link children's poor health with food insufficiency and family income.
} 


\section{Econometric Framework}

\section{Fixed-Effects Panel Data Model}

To estimate the effect of parental job loss on child health status, we first specify a reduced-form relationship. The main econometric model is a fixed-effects panel data model:

$$
H_{i h t}=\beta_{0}+\beta_{1} \text { jobloss }_{h t}+\beta_{2} H_{i h, t-1}+\beta_{3} X_{i h, t-1}+\beta_{4} W_{h, t-1}+\beta_{5} v_{t}+\mu_{i}+\varepsilon_{i h t}
$$

where $i$ indexes individual children, $h$ indexes household, and $t$ indexes time. $\quad H_{\text {iht }}$ is the health outcome of child $i$ in household $h$ at time $t$; jobloss $s_{h t}$ is a binary indicator variable showing whether the father (or mother) in household $h$ lost his (or her) job from time $t-1$ to $t ; X_{i h, t-1}$ is a vector of individual child $i$ 's observable characteristics at time $t-1 ; W_{h, t-1}$ is a vector of household-specific exogenous variables and parents' demographic and socioeconomic characteristics, if applicable, at time $t-1 ; v_{t}$ is a fixed wave effect; $\mu_{i}$ is an individual fixed effect accounting for all time-invariant factors that may affect child health; and $\varepsilon_{i h t}$ is a random error term.

The coefficient $\beta_{1}$ on the variable jobloss is our primary interest, capturing the impact of parental job loss on child health. We primarily estimate equation (1) with the fixed-effects model, separately for paternal job loss and maternal job loss, as the key independent variable. The lagged dependent varaiable, $H_{i h, t-1}$, is added to control for child $i$ 's initial health status before his/her mother or father lost the job. To test the robustness of the results, we have two specifications for equation (1) with or without control for lagged health status of the children.

To capture the heterogeneous effects of parental job loss on child health, we 
interact the parental job loss indicator with some demographic variables in equation (1), and examine whether parental job loss has differential effects for younger vs. older children, boys vs. girls, children in high- vs. low-income families, and children in larger vs. smaller families:

$H_{i h t}=\beta_{0}+\beta_{1}$ jobloss $_{h t}+$ jjobloss $_{h t} * D_{i h, t-1}+\beta_{2} H_{i h, t-1}+\beta_{3} X_{i h, t-1}+\beta_{4} W_{h, t-1}+\beta_{5} v_{t}+\mu_{i}+\varepsilon_{i h t}$

where $D$ may be a dummy variable for child age, gender of the child, household income level, or household size. The coefficient $\delta$ on the interaction term reflects the heterogeneous effects of parental job loss.

\section{Endogeneity and Instrumental Variable Approach}

Our key independent variables, parental job loss, may suffer from endogeneity problems. Two important sources of bias, omitted variables and simultaneity, need to be addressed. First, in the SOE or collective enterprises, layoff decisions are not random. Those who have lower work productivity may have higher chances of being laid off and are also more likely to have children with worse health status. Second, the father or mother's work decision may also be affected by child health status.

During our study period 1991-2006, the SOE retrenchment is an exogenous shock for individual households and thus alleviates to some degree the endogenous selection of parental employment status. In the model, we include productivity information on the parents, such as their education and health, to control for the observable component of the nonrandom layoff. In addition, our fixed-effects model 
also controls for unobserved time-invariant household background. To further deal with unobserved time-varying parents' characteristics and simultaneous bias, we use the instrumental-variable approach to correct for endogeneity of parental job-loss status. The first-stage equation is specified as

$$
\text { jobloss }_{i h t}=\alpha_{0}+\alpha_{1} Z_{1 h, t-1}+\alpha_{2} Z_{2 c, t-1}+\alpha_{3} H_{i h, t-1}+\alpha_{4} X_{i h, t-1}+\alpha_{5} W_{h, t-1}+\alpha_{6} v_{t}+e_{i h t}
$$

where $c$ indexes community or county. $\quad Z_{1 h, t-1}$ and $Z_{2 c, t-1}$ are instrumental variables for parental job loss. $Z_{1 h, t-1}$ includes two binary variables indicating whether both parents worked in SOEs, collective enterprises, or in public institutions at time $t^{-1}$, namely, before layoff. During the SOE retrenchment period, there was a policy that a couple should not be both laid off at the same time. If a couple both worked in SOEs, collective enterprises, or public institutions, one was less likely to be laid off when his/her spouse has already lost the job.

$Z_{2 c, t-1}$ includes three variables at the community or county level: the county-level layoff rate excluding the child's parents; an indicator whether there is an open trade area near this neighborhood (within two hours by bus); and the number of private enterprises in this community. The county-level layoff rate indicates the degree of SOE labor retrenchment in the county, which is supposed to be positively correlated with the likelihood of individual job loss. The other two instruments - the indicator of an open trade area and the number of private enterprises in the community - reflect the job opportunities in the market, which are also expected to be positively associated with one's decision to leave SOE or collective enterprises. In addition, these instruments have no direct relationship with child health status. 


\section{Empirical Results}

\section{Main Results}

The main results are based on the main measure in Table 1 as mentioned in Section III, and are reported in Tables 2 and 3.

Table 2 shows the effect of paternal job loss on child outcome variables: the height-for-age $z$-score and weight-for-age $z$-score. For both health outcomes, we have two specifications. One controls for lagged $z$-scores of the children, and the other does not. For both specifications, it is clear that paternal job loss has a significant negative effect on height-for-age $z$-score as well as weight-for-age $z$-score of the children.

Table 3 presents the results for maternal job loss, with similar specifications. For both outcomes and both specifications, the estimated coefficients of the maternal job-loss dummy are all negative but insignificant. This finding is consistent with the literature on maternal job leaving in developed countries (Baker and Milligan, 2008). The difference in effects between paternal job loss and maternal job loss is striking. We look into this issue in detail in the following subsection.

----Table 3-----

To facilitate the interpretation of our results, we translate the coefficients of the paternal job loss on the $z$-scores into actual height and weight of boys and girls at different ages, as shown in Figure 1. Take the average 9-year-old boy, for example: he would be about 2 centimeters shorter and 2 kilograms lighter if his father had lost 
his job. ${ }^{9}$

----Figure 1-----

From both tables, we also find that children in an intact family are healthier (see the coefficients of presence of mother and presence of father), especially if the one who lost his job is the father.

One potential threat to our findings is that during the SOE retrenchment, the employers could symmetrically lay off less healthy or less productive workers (e.g., less educated workers). First, from Table 1, there are no significant differences between parents in the lost-job families and the non-lost-job families in education level, height, weight, and BMI. Second, we control for parental characteristics in our models, and this corrects the possible bias induced by the observables.

It also could be the case that lost-job workers differ from non-lost-job workers in unobserved characteristics. We apply the instrumental-variable approach to tackle this issue in the following subsection 3.

Longer duration of unemployment may have more negative influence on the household income, and may also have more severe effects of psychological distress, and be more likely to induce risky behavior, etc. (Rowley and Feather, 1987; Mossakowski, 2008). In Table 4, we further examine the effect of the duration of parents' job loss on their children's health. We construct the variable of job loss duration based on the working history obtained from different waves, and divide the

\footnotetext{
${ }^{9}$ Baten and Bohm (2008) find that even in the relatively wealthy Eastern Germany, during 1994 to 2006, parental unemployment causes the children to be 1-2 centimeters shorter. Maccini and Yang (2009) find that women with $20 \%$ higher rainfall in their year of birth attain 0.57 -centimeter-greater height.
} 
job loss duration into three levels: job lost for one wave, two consecutive waves, or three consecutive waves. The top panel reports the selected coefficients on key explanatory variables for fathers, and the bottom panel for mothers. It is clear that the longer the duration of paternal job loss, the bigger the negative effects on the children's health. Though the negative effects of maternal job loss are also increasing in the duration, none is statistically significant.

----Table 4-----

In Table 5, we look into the health impact of the worst scenario: that both parents lose their jobs. To examine this situation, we use two samples. First, we use the full sample that we used in the previous analysis, i.e., the sample including single-parent families. Not surprisingly, if both parents lose their jobs, the negative impact on child health is almost twice as big as that when only father lost his job. If we restrict our sample to children from two-parent families, the negative effect is even bigger if both parents lose their jobs.

----Table 5-----

\section{Heterogeneous Effects}

In Table 6, we study heterogeneous effects resulting from parental job loss for different subpopulations. First, we examine if the parental job loss has differential effect according to the children's age. Due to the limitation of our sample size, we divide the children into only two age groups: 0 to 6 years old and 6 to 18 years old. We find that paternal job loss has a larger negative effect on height $z$-scores of the younger children, but a larger negative impact on weight $z$-scores of the older children. 
In contrast, maternal job loss has no significant effect for either age group.

----Table 6-----

Second, we investigate the gender dimension. It is interesting that for the outcome of height $z$-score, boys suffer more from paternal job loss, but girls suffer more from maternal job loss. This is consistent with the intrahousehold bargaining story. Li and Wu (2011) find that the wife's and husband's relative bargaining power affects the resource allocation for boys and girls within a Chinese family. For weight, the distinction is not so clear.

Third, we look into children in poor families and in rich families. We find that for poor households (income below the 30th percentile), parental job loss is devastating for the children's health. For either health outcome, height or weight $z$-scores, both paternal job loss and maternal job loss have a significant negative effect on children's health for low-income households. For rich households (income above the 30th percentile), the effect of parental job loss is small in magnitude and insignificant. This differs from findings in Ruhm (2008), which is based on U.S. data.

The last aspect we study is the size of the household. We divide the households into two categories: those with more than two adults, and the rest. We find that children in the smaller households are more vulnerable to parental job loss. One possible interpretation behind this finding is that larger households can cope with the income shock better through social-family networks by risk sharing (De Weerdt and Dercon, 2006). 


\section{Robustness Check}

In this subsection, we carry out two robustness checks. We experiment with alternative definitions of job loss, as we discussed earlier. And we apply an instrumental-variable approach to deal with potential endogenous employment status of the parents.

As we discussed in Section III and summarized in Table 1, we construct two different samples and experiment with two definitions of job loss status. The results from the four combinations are reported in Appendix Table A2. The results associated with the main measure in both Panel A: Father and Panel B: Mother are the main results we just discussed. The other results, based on alternative definitions of job loss and different samples, are all consistent with our main results that paternal job loss and maternal job loss have different effects on children's health; the impact of paternal job loss is significantly negative, and the impact of maternal job loss is insignificant, though it is still negative. In the next subsection, we attempt to understand this phenomenon.

As discussed earlier, one potential threat to our main findings is that during the labor market restructuring period, the SOEs could symmetrically lay off less healthy or less productive workers. Besides differing in observed characteristics, the lost-job workers could differ from non-lost-job workers in unobserved characteristics. We apply an instrumental-variable approach to tackle this issue. The instrumental variables include two binary variables indicating whether both parents worked in public institutions, in SOEs, or collective enterprises before layoff; the county-level 
layoff rate excluding the child's parents; an indicator for whether there is an open trade area near the neighborhood; and the number of private enterprises in the community.

These instruments pass the overidentification test, but may be weak instruments according to the low values of the first-stage $F$-statistic. Therefore, we employ the limited-information maximum likelihood (LIML) estimation method, which is robust to the weak-instrument case (Chao and Swanson, 2005).

Appendix Table 3A presents estimates based on the instrumental variable approach. Consistent with the fixed-effects results shown in Table 2 and Table 3, the IV estimation results suggest that paternal job loss significantly reduces child height $z$-scores by 0.68 units, whilst maternal job loss has no significant effect on child health. The endogeneity tests indicate that the exogeneity of paternal or maternal job loss cannot be rejected at any significance level. So our main results based on fixed-effects estimation are valid.

\section{Channels}

To understand why paternal job loss and maternal job loss have differential impacts, we also investigate several channels between parental job loss and children's health as hypothesized in Grossman's model.

First, we look into the effect of parental job loss on the children's health through the budget constraint. From Table 7, we can see that paternal job loss will significantly reduce household total income as well as per capita income, whilst the 
impact on income resulting from maternal job loss is insignificant. ${ }^{10}$ This finding supports our main results: only paternal job loss has significant negative effect on children's health. This channel is a very plausible and important one, given that China still lacks a well-functioning unemployment insurance system.

----Table 7-----

The above argument is further strengthened by the results in Table 8 . In Table 8 we examine the relationship between parental job loss and children's nutrition intake. The results in this table are consistent with Table 8. Maternal job loss does not affect the nutrition intake of the children; however, children's nutrition intakes from low-income families with lost-job fathers become significantly less.

----Table 8-----

Second, we examine the effect of job loss on parental time allocation. Table 9 shows the regression results for children's health care (immunization and preventive care) utilization. All the key estimates are insignificant, except that children from low-income families with lost-job mothers are more likely to receive immunization. The rationale behind this is that in China, children's immunization is almost free. A lost-job mother has more time to take her child to utilize this service.

----Table 9-----

This time allocation effect is further supported by the findings in Table 10 . Table 10 shows that a lost-job mother increases her time allocation to home production, such as taking care of the child, buying food, and cooking, but this is not

\footnotetext{
${ }^{10}$ Household income reduction is 8.3 thousand Chinese yuan due to paternal job loss; this number is around half of the average household annual income (16.2 thousand Chinese yuan) in our sample.
} 
the case for a lost-job father. Our results are consistent with other studies; for example, using U.S. data, Cawley and Liu (2007) find employed women spend significantly less time on activities such as cooking and playing with their children, and are more likely to purchase prepared foods. They think that this is a plausible mechanism linking maternal employment with childhood obesity.

----Table 10-----

The third issue we investigate is the behavior change of family members resulting from parental job loss. Specifically, we look into risky behavior, such as smoking. We find that after paternal job loss, both the child and the father are more likely to smoke, but this is not true if the lost job is that of the mother (Table 11).

----Table 11-----

In the Tables 2 and 3, we find that children in an intact family are less vulnerable to the negative effect of parental job loss. An important question worthy of investigating is whether parental job loss destabilizes the family, and hence affects the children adversely. This is the last issue we investigate in this paper; we do not find evidence that paternal or maternal job loss increases the divorce rate (see Appendix Table A4). ${ }^{11,} 12$.

\section{Conclusions}

In this paper, we investigate the impact of parental job loss on the health outcomes of their children, using the CHNS data 1991-2006. The results consistently

\footnotetext{
${ }^{11}$ In the literature there is evidence suggesting that unemployment is likely to lead to marriage dissolution, e.g., Jensen and Smith (1990). However, Oreopoulos, Page, and Stevens (2008) find that the evidence of a relationship between job loss and divorce among fathers is very weak.

${ }^{12}$ We must note that we observe less than 10 divorce cases in our sample. This will not allow us to estimate the relationship between job loss and divorce accurately.
} 
show that paternal job loss has significant negative effect on children's health, whilst maternal job loss has no significant effect. The rationale behind the findings is that the lost-job mothers are likely to increase their time to take care of their children and this may alleviate the negative effect resulting from job loss; also, the income loss resulting from maternal job loss is much smaller. Lost-job fathers are also more likely to exhibit risky behavior, such as smoking, and this may adversely affect their children's health.

We also study heterogeneous effects resulting from parental job loss for different groups. We find that the younger the children are, the bigger the negative effect resulting from paternal job loss. We also find that the boy suffers more from paternal job loss and the girl suffers more from maternal job loss if we use height as a measure for health. In addition, children from low-income households or from small households are more vulnerable to parental job loss.

One drawback of our paper is that our job-loss variables do not exactly measure the laid-off status of the SOE worker, though our main definition of job loss is very close to the definition of an SOE layoff. Nonetheless, our main results are robust to alternative definitions of job loss and to various specifications.

During China's transition from a planned economy to a market economy, a lot of studies and discussions have dealt with the improvement of efficiency. Equity issues have drawn less attention. Our study suggests that during the transition, children become victims, which in turn could hurt the economy in the long run (Bartik, 2011). It is important to take this into consideration when formulating future policies. 


\section{References:}

Alaimo, K., C. Olson, E. Frongillo, and R. Briefel (2001), "Food Insufficiency, Family Income, and Health in US Preschool and School-Aged Children," American Journal of Public Health, 91(5), pp. 781-786.

Appleton, S., L. Song, and Q. Xia (2005), "Has China Crossed the River? The Evolution of Wage Structure in Urban China during Reform and Retrenchment," Journal of Comparative Economics, 33(4), pp. 644-663.

Baker, M., and K. Milligan (2008), "Maternal Employment, Breastfeeding, and Health: Evidence from Maternity Leave Mandates," Journal of Health Economics, 27(4), pp. 871-887.

Bartik, T. J. (2011), Investing in Kids: Early Childhood Programs and Local Economic Development. Kalamazoo, MI: W.E. Upjohn Institute for Employment Research.

Baten, J., and A. Bohm (2008), "Trends of Children's Height and Parental Unemployment: A Large-Scale Anthropometric Study on Eastern Germany, 1994-2006," CESifo Working Paper No. 2189.

Becker, G. S. (1964), Human Capital (New York: Columbia University Press for the National Bureau of Economic Research).

Becker, G. S. (1965), “A Theory of the Allocation of Time,” Economic Journal, 75, pp. $493-517$.

Case, A., D. Lubotsky, and C. Paxson (2002), "Economic Status and Health in Childhood: The Origins of the Gradient," American Economic Review, 92(5), 
pp. $1308-1334$.

Cawley, J., and F. Liu (2007), "Maternal Employment and Childhood Obesity: A Search for Mechanisms in Time Use Data," NBER Working Papers 13600, National Bureau of Economic Research, Inc.

Chao, J.C., and N.R. Swanson (2005), “Consistent Estimation with a Large Number of Weak Instruments,” Econometrica, 73(5), pp. 1673-1692.

Chen, Y. and H. Li (2009), "Mother's Education and Child Health: Is There a Nurturing Effect?” Journal of Health Economics, 28(2), pp.413-426.

Chen, Y. and L. Zhou (2007), “The Long-term Health and Economic Consequences of the 1959-1961 Famine in China," Journal of Health Economics, 26(4), pp. $659-681$.

Cunha, F., J. Heckman, and S. Schennach (2010), "Estimating the Technology of Cognitive and Noncognitive Skill Formation,” NBER Working Papers 15664, National Bureau of Economic Research, Inc.

Currie, J., and E. Moretti (2007), "Biology as Destiny? Short- and Long-Run Determinants of Intergenerational Transmission of Birth Weight," Journal of Labor Economics, 25, pp. 231-264.

Currie, J., and M. Stabile (2003), "Socioeconomic Status and Child Health: Why Is the Relationship Stronger for Older Children?" American Economic Review, 93(5), pp. 1813-1823.

Cutler, D. M., and E. Richardson (1997), "Measuring the Health of the U.S. Population," Brookings Papers on Economic Activity: Microeconomics 1997, 
pp. 217-271.

De Weerdt, J., and S. Dercon (2006), "Risk-sharing Networks and Insurance against Illness," Journal of Development Economics, 81(2), pp. 337-356.

Dong, X., and L. Xu (2009), "Labor Restructuring in China: Toward a Functioning Labor Market,” Journal of Comparative Economics, 37(2), pp. 287-305.

Field, M. J., and M. R. Gold (1998), Summarizing Population Health: Directions for the Development and Application of Population Metrics (Washington, D.C.: National Academy Press).

Fuchs, V. R. (1966), "The Contribution of Health Services to the American Economy," Milbank Memorial Fund Quarterly, 66, pp. 65-102.

Gennetian, L. A., H. D.Heather, A. S. London, and L. M. Lopoo (2010), "Maternal employment and the health of low-income young children," Journal of Health Economics, 29(3), pp. 353-363.

Grossman, M. (1972), "On the Concept of Health Capital and the Demand for Health," Journal of Political Economy, 80(2), pp. 223-255.

Grossman, M. (2000), “The Human Capital Model of the Demand for Health,” in: J. P. Newhouse \& A. J. Culyer (eds.), Handbook of Health Economics, 1A, pp. 347-408 (Amsterdam: Elsevier Science).

Jensen, P., and N. Smith (1990), "Unemployment and Marital Dissolution,” Journal of Population Economics, 3(3), pp. 215-29.

Knight, J., and L. Song (2003), "Increasing Urban Wage Inequality in China," Economics of Transition, 11(4), pp. 597-619. 
Li, L., and X. Wu (2011), “Gender of Children, Bargaining Power, and Intrahousehold Resource Allocation in China," Journal of Human Resources, 46(2), pp. $295-316$.

Liu, Y. (2002), "Reforming China's Urban Health Insurance System," Health Policy, 60(2), pp. 133-150.

Liu, E., C. Hsiao, T. Matsumoto, and S. Chou (2009), "Maternal Full-Time Employment and Overweight Children: Parametric, Semi-parametric, and Non-parametric Assessment," Journal of Econometrics, 152(1), pp. 61-69.

Maccini, S., and D. Yang (2009), "Under the Weather: Health, Schooling, and Economic Consequences of Early-Life Rainfall," American Economic Review, 99(3), pp. 1006-26.

Ministry of Health (2005), China Health Statistical Yearbook 2005. Beijing: Peking Union Medical Press (in Chinese).

Montgomery, S.M., D.G. Cook, M.J. Bartley, and M.E.J. Wadsworth (1998), “Unemployment, Cigarette Smoking, Alcohol Consumption and Body Weight in Young Men," European Journal of Public Health, 8, pp. 21-27.

Morrill, M., (2011), "The Effects of Maternal Employment on the Health of School-Age Children," Journal of Health Economics, 30(2), pp. 240-257.

Mossakowski, K. (2008), "Is the Duration of Poverty and Unemployment a Risk Factor for Heavy Drinking?” Social Science \& Medicine, 67(6), pp. 947-955.

Mushkin, S. J. (1962), "Health as an Investment," Journal of Political Economy, 70(5), pp. 129-157. 
Oreopoulos, P., M. Page, and A. Stevens (2008), “The Intergenerational Effects of Worker Displacement," Journal of Labor Economics, 26(3), pp. 455-483.

Rowley, K. M., and N. T. Feather (1987), “The Impact of Unemployment in Relation to Age and Length of Unemployment," Journal of Occupational Psychology, 60, pp. 323-332.

Ruhm, C. (2008), "Maternal Employment and Adolescent Development," Labour Economics, 15(5), pp. 958-983.

Strauss, J., and D. Thomas (1998), "Health, Nutrition, and Economic Development," Journal of Economic Literature, 36(2), pp. 766-817.

van den Berg, G., M. Lindeboom, and F. Portrait (2006), "Economic Conditions Early in Life and Individual Mortality," American Economic Review, 96(1), pp. 290-302.

Vogli, R.D., and M. Santinello (2005), “Unemployment and Smoking: Does Psychosocial Stress Matter?” Tobacco Control, 14, pp. 389-395.

World Bank (2007), China's Modernizing Labor Market: Trends and Emerging Challenges.

Xu, L., Y. Wang, C.D. Collins, and S. Tang (2007), “Urban Health Insurance Reform and Coverage in China Using Data from National Health Services Surveys in 1998 and 2003," BMC Health Services Research, 3, pp. 7-37. 
Figure 1. The Magnitude of the Effect of Paternal Job Loss on Child Health

Panel A: Effect on Child Height

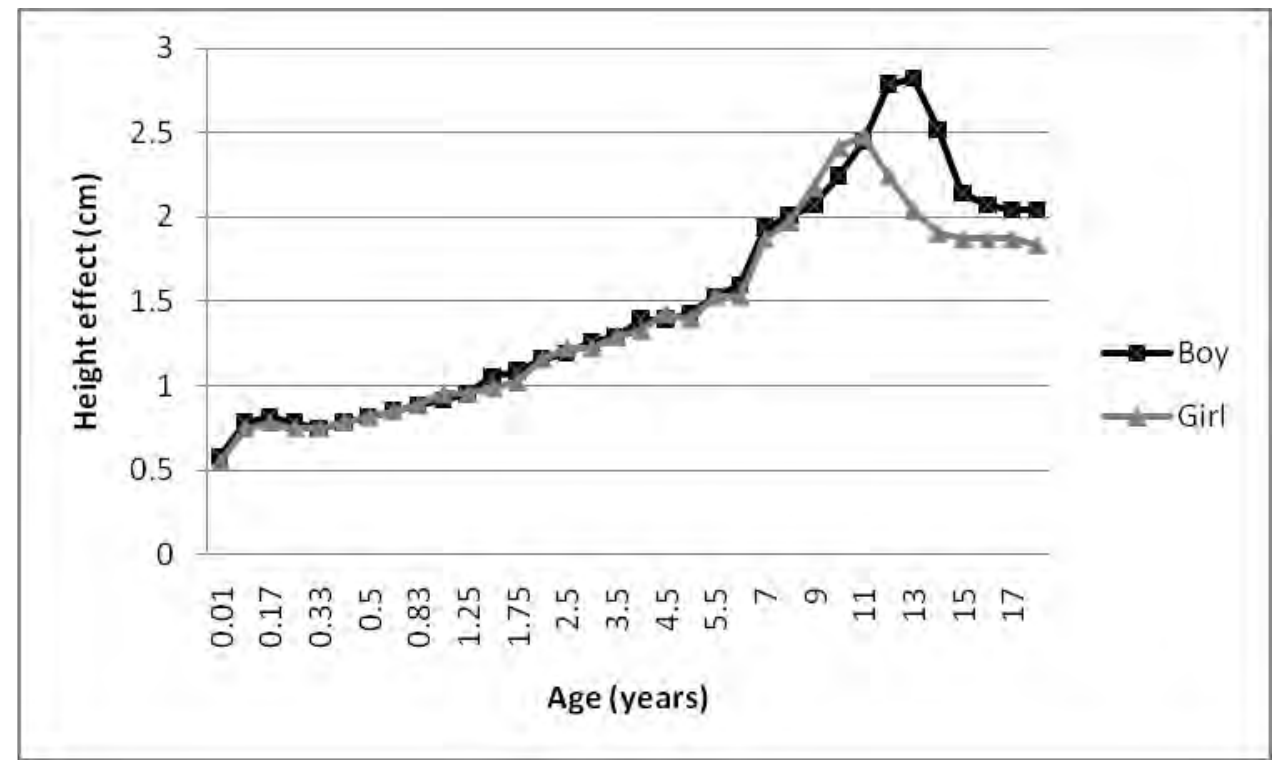

\section{Panel B: Effect on Child Weight}

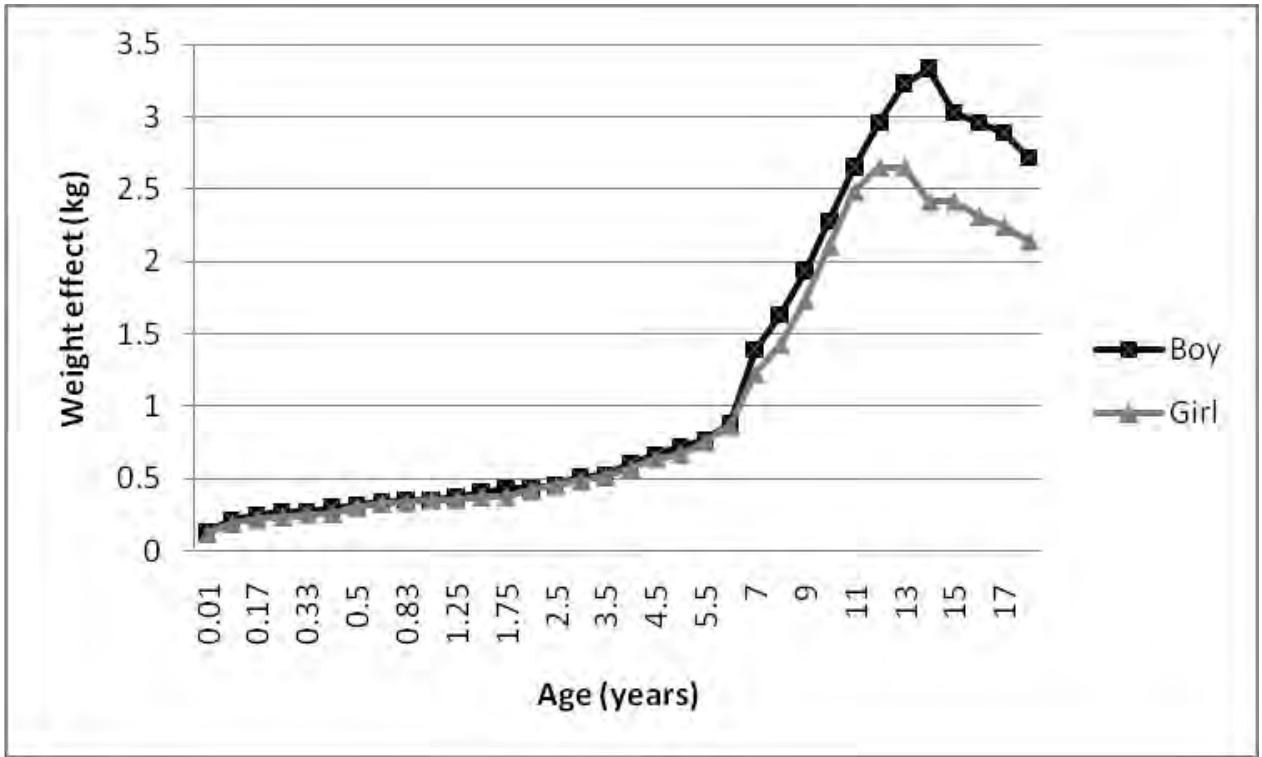

Note: The effect on height-for-age $z$-score is 0.33 , and on weight-for-age $z$-score is 0.38 . We translate the $z$-scores into actual height and weight based on the body development of Chinese urban children in 1995 (China Health Statistics, 2004 and 2005). 
Table 1. Measures of Job Loss from Time $t-1$ to Time $t$

\begin{tabular}{l|l|l|l}
\hline Binary indicator & $\begin{array}{l}\text { Employer at } \\
\boldsymbol{t} \mathbf{- 1}\end{array}$ & Job Loss: 1 & No Job Loss: 0 \\
\hline Main measure & $\begin{array}{l}\text { Public } \\
\text { institutions, } \\
\text { SOEs, or } \\
\text { collective } \\
\text { enterprises }\end{array}$ & $\begin{array}{l}\text { From full-time to part-time jobs, } \\
\text { or from work to unemployed }\end{array}$ & $\begin{array}{l}\text { Job stays the } \\
\text { same. }\end{array}$ \\
\hline $\begin{array}{l}\text { Alternative } \\
\text { measure 1 }\end{array}$ & $\begin{array}{l}\text { Public } \\
\text { institutions, } \\
\text { SOEs, or } \\
\text { collective } \\
\text { enterprises }\end{array}$ & $\begin{array}{l}\text { From full-time to part-time jobs, } \\
\text { from work to unemployed, or } \\
\text { from work to being out of labor } \\
\text { market }\end{array}$ & $\begin{array}{l}\text { Job stays the } \\
\text { same. }\end{array}$ \\
\hline $\begin{array}{l}\text { Alternative } \\
\text { measure 2 }\end{array}$ & $\begin{array}{l}\text { All, including } \\
\text { private } \\
\text { enterprises }\end{array}$ & $\begin{array}{l}\text { From full-time to part-time jobs, } \\
\text { or from work to unemployed }\end{array}$ & $\begin{array}{l}\text { Job stays the } \\
\text { same. }\end{array}$ \\
\hline $\begin{array}{l}\text { Alternative } \\
\text { measure 3 }\end{array}$ & $\begin{array}{l}\text { All, including } \\
\text { private } \\
\text { enterprises }\end{array}$ & $\begin{array}{l}\text { From full-time to part-time jobs, } \\
\text { from work to unemployed, or } \\
\text { from work to being out of labor } \\
\text { market }\end{array}$ & $\begin{array}{l}\text { Job stays the } \\
\text { same. }\end{array}$ \\
\hline
\end{tabular}


Table 2. The Effect of Paternal Job Loss on Child Health (Fixed-Effects Estimation controlling for $X_{t-1}$ )

\begin{tabular}{|c|c|c|c|c|}
\hline & \multicolumn{2}{|c|}{$\begin{array}{c}\text { Height-for-age } z \text {-score } \\
\text { HAZ }(t)\end{array}$} & \multicolumn{2}{|c|}{$\begin{array}{c}\text { Weight-for-age } z \text {-score } \\
\text { WAZ }(t)\end{array}$} \\
\hline & (1) & (2) & (3) & (4) \\
\hline Paternal job loss & $\begin{array}{c}-\mathbf{0 . 3 3} * * \\
(0.13)\end{array}$ & $\begin{array}{c}\mathbf{- 0 . 3 4} * * * \\
(0.13)\end{array}$ & $\begin{array}{c}-\mathbf{- 0 . 3 8} * * \\
(0.15)\end{array}$ & $\begin{array}{c}\mathbf{- 0 . 3 4} * * * \\
(0.15)\end{array}$ \\
\hline $\operatorname{HAZ}(t-1)$ & & $\begin{array}{c}-0.17 * * * \\
(0.05)\end{array}$ & & \\
\hline $\mathrm{WAZ}(t-1)$ & & & & $\begin{array}{c}-0.32 * * * \\
(0.06)\end{array}$ \\
\hline Father's age & $\begin{array}{c}0.55 \\
(0.58)\end{array}$ & $\begin{array}{c}0.66 \\
(0.56)\end{array}$ & $\begin{array}{l}-0.76 \\
(0.65)\end{array}$ & $\begin{array}{r}-0.39 \\
(0.63)\end{array}$ \\
\hline Father's education & $\begin{array}{c}0.01 \\
(0.07)\end{array}$ & $\begin{array}{c}0.01 \\
(0.07)\end{array}$ & $\begin{array}{c}0.02 \\
(0.08)\end{array}$ & $\begin{array}{c}0.04 \\
(0.07)\end{array}$ \\
\hline Father's height & $\begin{array}{l}-0.08 \\
(0.08)\end{array}$ & $\begin{array}{l}-0.06 \\
(0.08)\end{array}$ & & \\
\hline Father's BMI & $\begin{array}{l}-0.06^{*} \\
(0.04)\end{array}$ & $\begin{array}{l}-0.05 \\
(0.04)\end{array}$ & $\begin{array}{c}0.02 \\
(0.04)\end{array}$ & $\begin{array}{c}0.04 \\
(0.04)\end{array}$ \\
\hline Low household income & $\begin{array}{c}0.06 \\
(0.09)\end{array}$ & $\begin{array}{c}0.06 \\
(0.09)\end{array}$ & $\begin{array}{c}0.14 \\
(0.10)\end{array}$ & $\begin{array}{c}0.12 \\
(0.10)\end{array}$ \\
\hline High household income & $\begin{array}{c}0.08 \\
(0.10)\end{array}$ & $\begin{array}{c}0.09 \\
(0.10)\end{array}$ & $\begin{array}{c}0.01 \\
(0.11)\end{array}$ & $\begin{array}{c}0.03 \\
(0.11)\end{array}$ \\
\hline Household head is male & $\begin{array}{c}0.23 \\
(0.23)\end{array}$ & $\begin{array}{c}0.20 \\
(0.22)\end{array}$ & $\begin{array}{l}-0.07 \\
(0.26)\end{array}$ & $\begin{array}{l}-0.15 \\
(0.25)\end{array}$ \\
\hline No. of children & $\begin{array}{l}-0.16 \\
(0.12)\end{array}$ & $\begin{array}{l}-0.15 \\
(0.12)\end{array}$ & $\begin{array}{l}-0.16 \\
(0.13)\end{array}$ & $\begin{array}{l}-0.13 \\
(0.13)\end{array}$ \\
\hline No. of adults & $\begin{array}{l}-0.11 \\
(0.08)\end{array}$ & $\begin{array}{l}-0.11 \\
(0.08)\end{array}$ & $\begin{array}{l}-0.15 \\
(0.09)\end{array}$ & $\begin{array}{l}-0.12 \\
(0.09)\end{array}$ \\
\hline Child has health insurance & $\begin{array}{l}0.18^{*} \\
(0.10)\end{array}$ & $\begin{array}{l}0.18^{*} \\
(0.10)\end{array}$ & $\begin{array}{l}-0.07 \\
(0.11)\end{array}$ & $\begin{array}{c}0.01 \\
(0.11)\end{array}$ \\
\hline Child ages $6-12$ & $\begin{array}{c}0.22 \\
(0.14)\end{array}$ & $\begin{array}{c}0.21 \\
(0.13)\end{array}$ & $\begin{array}{c}0.08 \\
(0.15)\end{array}$ & $\begin{array}{c}0.07 \\
(0.15)\end{array}$ \\
\hline Child ages 12 and above & $\begin{array}{l}0.38^{*} \\
(0.21)\end{array}$ & $\begin{array}{l}0.38^{*} \\
(0.21)\end{array}$ & $\begin{array}{c}0.20 \\
(0.24)\end{array}$ & $\begin{array}{c}0.15 \\
(0.23)\end{array}$ \\
\hline Child is a student & $\begin{array}{c}0.08 \\
(0.10)\end{array}$ & $\begin{array}{c}0.09 \\
(0.10)\end{array}$ & $\begin{array}{c}0.14 \\
(0.12)\end{array}$ & $\begin{array}{c}0.17 \\
(0.11)\end{array}$ \\
\hline Presence of mother & $\begin{array}{c}0.59 * * \\
(0.27)\end{array}$ & $\begin{array}{l}0.62 * * \\
(0.27)\end{array}$ & $\begin{array}{l}0.61 * * \\
(0.31)\end{array}$ & $\begin{array}{c}0.62 * * \\
(0.29)\end{array}$ \\
\hline Constant & $\begin{array}{c}-5.04 \\
(23.60)\end{array}$ & $\begin{array}{l}-12.24 \\
(23.21)\end{array}$ & $\begin{array}{c}24.94 \\
(21.97)\end{array}$ & $\begin{array}{l}11.64 \\
(21.23)\end{array}$ \\
\hline Control of wave dummies & Yes & Yes & Yes & yes \\
\hline No. of observations & 1104 & 1104 & 1104 & 1104 \\
\hline
\end{tabular}

Note: $\quad$ Standard errors in parentheses; $* p<0.10, * * p<0.05$, *** $p<0.01$. 
Table 3. The Effect of Maternal Job Loss on Child Health (Fixed-Effects Estimation controlling for $X_{t-1}$ )

\begin{tabular}{|c|c|c|c|c|}
\hline & \multicolumn{2}{|c|}{$\begin{array}{c}\text { Height-for-age } z \text {-score } \\
\text { HAZ }(t)\end{array}$} & \multicolumn{2}{|c|}{$\begin{array}{c}\text { Weight-for-age } z \text {-score } \\
\text { WAZ }(t)\end{array}$} \\
\hline & (1) & $(2)$ & (3) & (4) \\
\hline Maternal job loss & $\begin{array}{l}-0.28 \\
(0.18)\end{array}$ & $\begin{array}{l}-0.26 \\
(0.18)\end{array}$ & $\begin{array}{l}-0.17 \\
(0.17)\end{array}$ & $\begin{array}{l}-0.21 \\
(0.16)\end{array}$ \\
\hline $\operatorname{HAZ}(t-1)$ & & $\begin{array}{c}-0.14 * * * \\
(0.05)\end{array}$ & & \\
\hline $\mathrm{WAZ}(t-1)$ & & & & $\begin{array}{c}-0.31 * * * \\
(0.05)\end{array}$ \\
\hline Mother's age & $\begin{array}{c}0.86 \\
(0.61)\end{array}$ & $\begin{array}{c}0.88 \\
(0.60)\end{array}$ & $\begin{array}{l}-0.35 \\
(0.58)\end{array}$ & $\begin{array}{l}-0.16 \\
(0.56)\end{array}$ \\
\hline Mother's education & $\begin{array}{l}-0.00 \\
(0.06)\end{array}$ & $\begin{array}{l}-0.01 \\
(0.06)\end{array}$ & $\begin{array}{l}-0.07 \\
(0.06)\end{array}$ & $\begin{array}{l}-0.09 \\
(0.06)\end{array}$ \\
\hline Mother's height & $\begin{array}{c}0.03 \\
(0.09)\end{array}$ & $\begin{array}{c}0.03 \\
(0.08)\end{array}$ & & \\
\hline Mother's BMI & $\begin{array}{c}0.04 \\
(0.03)\end{array}$ & $\begin{array}{c}0.04 \\
(0.03)\end{array}$ & $\begin{array}{c}0.00 \\
(0.03)\end{array}$ & $\begin{array}{c}0.01 \\
(0.03)\end{array}$ \\
\hline Low household income & $\begin{array}{c}0.09 \\
(0.09)\end{array}$ & $\begin{array}{c}0.10 \\
(0.09)\end{array}$ & $\begin{array}{c}0.12 \\
(0.09)\end{array}$ & $\begin{array}{c}0.11 \\
(0.09)\end{array}$ \\
\hline High household income & $\begin{array}{l}-0.05 \\
(0.11)\end{array}$ & $\begin{array}{l}-0.02 \\
(0.11)\end{array}$ & $\begin{array}{l}-0.09 \\
(0.11)\end{array}$ & $\begin{array}{l}-0.07 \\
(0.10)\end{array}$ \\
\hline Household head is male & $\begin{array}{l}0.05 \\
(0.26)\end{array}$ & $\begin{array}{l}-0.01 \\
(0.26)\end{array}$ & $\begin{array}{l}-0.42 * \\
(0.25)\end{array}$ & $\begin{array}{c}-0.46^{* *} \\
(0.24)\end{array}$ \\
\hline No. of children & $\begin{array}{l}-0.20^{*} \\
(0.12)\end{array}$ & $\begin{array}{l}-0.16 \\
(0.12)\end{array}$ & $\begin{array}{l}-0.03 \\
(0.11)\end{array}$ & $\begin{array}{c}0.01 \\
(0.11)\end{array}$ \\
\hline No. of adults & $\begin{array}{l}-0.11 \\
(0.09)\end{array}$ & $\begin{array}{l}-0.10 \\
(0.08)\end{array}$ & $\begin{array}{l}-0.02 \\
(0.08)\end{array}$ & $\begin{array}{l}-0.00 \\
(0.08)\end{array}$ \\
\hline Child has health insurance & $\begin{array}{c}0.06 \\
(0.12)\end{array}$ & $\begin{array}{c}0.04 \\
(0.12)\end{array}$ & $\begin{array}{c}-0.14 \\
(0.11)\end{array}$ & $\begin{array}{c}-0.14 \\
(0.11)\end{array}$ \\
\hline Child ages 6-12 & $\begin{array}{c}0.05 \\
(0.15)\end{array}$ & $\begin{array}{c}0.03 \\
(0.15)\end{array}$ & $\begin{array}{c}0.14 \\
(0.15)\end{array}$ & $\begin{array}{c}0.10 \\
(0.14)\end{array}$ \\
\hline Child ages 12 and above & $\begin{array}{c}0.21 \\
(0.24)\end{array}$ & $\begin{array}{c}0.19 \\
(0.24)\end{array}$ & $\begin{array}{l}0.45^{*} \\
(0.23)\end{array}$ & $\begin{array}{l}0.38^{*} \\
(0.22)\end{array}$ \\
\hline Child is a student & $\begin{array}{l}0.05 \\
(0.12)\end{array}$ & $\begin{array}{c}0.06 \\
(0.12)\end{array}$ & $\begin{array}{c}0.06 \\
(0.11)\end{array}$ & $\begin{array}{c}0.07 \\
(0.11)\end{array}$ \\
\hline Presence of father & $\begin{array}{c}0.23 \\
(0.39)\end{array}$ & $\begin{array}{c}0.28 \\
(0.38)\end{array}$ & $\begin{array}{l}0.94 * * \\
(0.37)\end{array}$ & $\begin{array}{c}1.11 * * * \\
(0.36)\end{array}$ \\
\hline Constant & $\begin{array}{l}-34.08 \\
(24.16)\end{array}$ & $\begin{array}{l}-34.82 \\
(23.89)\end{array}$ & $\begin{array}{c}11.13 \\
(18.73)\end{array}$ & $\begin{array}{c}4.62 \\
(17.90)\end{array}$ \\
\hline Control of wave dummies & Yes & Yes & Yes & Yes \\
\hline No. of observations & 1096 & 1096 & 1096 & 1096 \\
\hline
\end{tabular}

Note: $\quad$ Standard errors in parentheses; $* p<0.10, * * p<0.05, * * * p<0.01$. 
Table 4. The Effect of Duration of Parental Job Loss on Child Health

(Fixed-Effects Estimation Controlling for $X_{t-1}$ )

\begin{tabular}{|c|c|c|c|c|}
\hline & \multicolumn{2}{|c|}{$\begin{array}{l}\text { Height-for-age } z \text {-score } \\
\text { HAZ }(t)\end{array}$} & \multicolumn{2}{|c|}{$\begin{array}{l}\text { Weight-for-age } z \text {-score } \\
\text { WAZ }(t)\end{array}$} \\
\hline & $(1)$ & $(2)$ & (3) & (4) \\
\hline \multicolumn{5}{|c|}{ Panel A: Father } \\
\hline \multirow[t]{2}{*}{ Paternal job loss for 1 wave } & $-0.37 *$ & $-0.34 *$ & $-0.38 *$ & $-0.35 *$ \\
\hline & $(0.20)$ & $(0.20)$ & $(0.20)$ & $(0.20)$ \\
\hline \multirow[t]{2}{*}{ Paternal job loss for 2 waves } & -0.23 & -0.22 & -0.34 & -0.32 \\
\hline & $(0.24)$ & $(0.25)$ & $(0.25)$ & $(0.25)$ \\
\hline \multirow[t]{2}{*}{ Paternal job loss for 3 waves } & $-0.74 \#$ & $-0.74 \#$ & $-1.02 * *$ & $-1.01 * *$ \\
\hline & $(0.46)$ & $(0.45)$ & $(0.47)$ & $(0.47)$ \\
\hline \multirow[t]{2}{*}{ Low household income } & & $-0.17^{*}$ & & $-0.15 \#$ \\
\hline & & $(0.09)$ & & $(0.10)$ \\
\hline \multirow[t]{2}{*}{ High household income } & & 0.13 & & 0.11 \\
\hline & & $(0.10)$ & & $(0.10)$ \\
\hline \multirow[t]{2}{*}{ No. of observations } & 1122 & 1122 & 1122 & 1122 \\
\hline & Pan & Iother & & \\
\hline \multirow[t]{2}{*}{ Maternal job loss for 1 wave } & -0.03 & -0.03 & -0.12 & -0.12 \\
\hline & $(0.18)$ & $(0.18)$ & $(0.18)$ & $(0.18)$ \\
\hline \multirow[t]{2}{*}{ Maternal job loss for 2 waves } & 0.34 & 0.41 & -0.09 & -0.03 \\
\hline & $(0.37)$ & $(0.37)$ & $(0.37)$ & $(0.37)$ \\
\hline \multirow[t]{2}{*}{ Maternal job loss for 3 waves } & -0.74 & -0.60 & -0.79 & -0.68 \\
\hline & $(0.87)$ & $(0.86)$ & $(0.88)$ & $(0.88)$ \\
\hline \multirow[t]{2}{*}{ Low household income } & & $-0.15^{*}$ & & -0.12 \\
\hline & & $(0.09)$ & & $(0.09)$ \\
\hline \multirow[t]{2}{*}{ High household income } & & $0.16 \#$ & & 0.12 \\
\hline & & $(0.11)$ & & $(0.11)$ \\
\hline No. of observations & 1123 & 1123 & 1123 & 1123 \\
\hline
\end{tabular}

\section{Note:}

a) Standard errors in parentheses; \# $p<0.15, * p<0.10, * * p<0.05$, *** $p<0.01$.

b) Each regression includes whether household head is the father; numbers of children and adults; child's age; indicators for whether the child has health insurance and is a student; and year dummies.

c) For Panel A, other regressors include father's age, education, height, and BMI, and an indicator for the presence of mother in the household.

d) For Panel B, other regressors include mother's age, education, height, and BMI, and an indicator for the presence of father in the household. 
Table 5. The Effect of Both Parents' Job Loss on Child Health (Fixed-Effects Estimation Controlling for $X_{t-1}$ )

\begin{tabular}{|c|c|c|c|c|}
\hline & \multicolumn{2}{|c|}{$\begin{array}{c}\text { Height-for-age } z \text {-score } \\
\text { HAZ }(t)\end{array}$} & \multicolumn{2}{|c|}{$\begin{array}{c}\text { Weight-for-age } z \text {-score } \\
\text { WAZ }(t)\end{array}$} \\
\hline & $(1)$ & $(2)$ & (3) & $(4)$ \\
\hline \multicolumn{5}{|c|}{ Panel A: Full sample } \\
\hline Only father lost job & $\begin{array}{l}-0.10 \\
(0.14)\end{array}$ & $\begin{array}{l}-0.13 \\
(0.13)\end{array}$ & $\begin{array}{l}-0.14 \\
(0.14)\end{array}$ & $\begin{array}{l}-0.12 \\
(0.14)\end{array}$ \\
\hline Only mother lost job & $\begin{array}{l}-0.10 \\
(0.18)\end{array}$ & $\begin{array}{l}-0.10 \\
(0.17)\end{array}$ & $\begin{array}{l}-0.17 \\
(0.18)\end{array}$ & $\begin{array}{l}-0.19 \\
(0.18)\end{array}$ \\
\hline Both parents lost job & $\begin{array}{c}\mathbf{- 0 . 7 0}^{* * * *} \\
(0.26)\end{array}$ & $\begin{array}{c}-\mathbf{- 0 . 6 8 * * *} \\
(0.26)\end{array}$ & $\begin{array}{l}\mathbf{- 0 . 6 1 * *} \\
(0.28)\end{array}$ & $\begin{array}{l}-\mathbf{- 0 . 6 7 * *} \\
(0.26)\end{array}$ \\
\hline $\operatorname{HAZ}(t-1)$ & & $\begin{array}{c}-0.20 * * * \\
(0.04)\end{array}$ & & \\
\hline $\mathrm{WAZ}(t-1)$ & & & & $\begin{array}{c}-0.34 * * * \\
(0.05) \\
\end{array}$ \\
\hline No. of observations & 1255 & 1255 & 1255 & 1255 \\
\hline \multicolumn{5}{|c|}{ Panel B: Sample from two-parent families } \\
\hline Only father lost job & $\begin{array}{l}-0.20 \\
(0.22)\end{array}$ & $\begin{array}{l}-0.20 \\
(0.21)\end{array}$ & $\begin{array}{l}-0.15 \\
(0.24)\end{array}$ & $\begin{array}{l}-0.07 \\
(0.23)\end{array}$ \\
\hline Only mother lost job & $\begin{array}{c}0.28 \\
(0.29)\end{array}$ & $\begin{array}{c}0.34 \\
(0.29)\end{array}$ & $\begin{array}{l}-0.13 \\
(0.33)\end{array}$ & $\begin{array}{l}-0.08 \\
(0.31)\end{array}$ \\
\hline Both parents lost job & $\begin{array}{c}-\mathbf{1 . 3 3} * * * \\
(0.42)\end{array}$ & $\begin{array}{c}-\mathbf{1 . 3 5} * * * \\
(0.41)\end{array}$ & $\begin{array}{l}\mathbf{- 0 . 6 6} \\
(0.47)\end{array}$ & $\begin{array}{l}-\mathbf{0 . 8 0 *} \\
(0.44)\end{array}$ \\
\hline HAZ(t-1) & & $\begin{array}{l}-0.13 * * \\
(0.06)\end{array}$ & & \\
\hline WAZ(t-1) & & & & $\begin{array}{c}-0.38 * * * \\
(0.07) \\
\end{array}$ \\
\hline No. of observations & 838 & 838 & 838 & 838 \\
\hline
\end{tabular}

Note:

a) Standard errors in parentheses; * $p<0.10$, ** $p<0.05$, *** $p<0.01$.

b) Each regression included indicators for household income below the 30th percentile; household income above the 70th percentile; whether household head is the father; numbers of children and adults; child's age; indicators for whether the child has health insurance and is a student; and year dummies.

c) For Panel A, other regressors included mother's age, education, height, and BMI, which are interacted with an indicator of the presence of the mother in the household; father's age, education, height, and BMI, which are interacted with an indicator of the presence of the father in the household; and indicators for the presence of mother and father in the household.

d) For Panel B, other regressors included mother's age, education, height, and BMI, and father's age, education, height, and BMI. 
Table 6. Heterogeneous Effects of Parental Job Loss (Fixed-Effects Estimation Controlling for $X_{t-1}$ and $\left.Y_{t-1}\right)$

\begin{tabular}{|c|c|c|c|c|c|c|c|c|}
\hline \multicolumn{9}{|c|}{ Dependent variable: Height-for-age $z$-score $(\mathrm{HAZ}(t))$} \\
\hline & Age $0-6$ & $\begin{array}{l}\text { Age } \\
6-18\end{array}$ & Girl & Boy & $\begin{array}{c}\text { HH } \\
\text { income } \\
\text { below } \\
\text { 30th } \\
\text { percentile } \\
\end{array}$ & $\begin{array}{c}\text { HH } \\
\text { income } \\
\text { above } \\
\text { 30th } \\
\text { percentile }\end{array}$ & $\begin{array}{l}\text { No. of } \\
\text { adults } \\
\leqslant 2\end{array}$ & $\begin{array}{l}\text { No. of } \\
\text { adults } \\
>2\end{array}$ \\
\hline & $(1)$ & (2) & (3) & $(4)$ & $(5)$ & $(6)$ & (7) & (8) \\
\hline & \multicolumn{8}{|c|}{ Panel A: Father } \\
\hline Paternal job loss & $\begin{array}{c}\mathbf{- 3 . 4 4} * * * \\
(0.64)\end{array}$ & $\begin{array}{c}-\mathbf{- 0 . 4 5} * * * \\
(0.16)\end{array}$ & $\begin{array}{l}-0.28 \\
(0.23)\end{array}$ & $\begin{array}{c}\mathbf{- 0 . 3 9} * * \\
(0.16)\end{array}$ & $\begin{array}{c}\mathbf{- 1 . 2 0} * * * \\
(0.42)\end{array}$ & $\begin{array}{l}-0.21 \\
(0.19)\end{array}$ & $\begin{array}{l}-\mathbf{0 . 3 8 *} \\
(0.20)\end{array}$ & $\begin{array}{l}-0.24 \\
(0.21)\end{array}$ \\
\hline \multirow[t]{2}{*}{ No. of observations } & 208 & 896 & 533 & 571 & 334 & 770 & 701 & 403 \\
\hline & \multicolumn{8}{|c|}{ Panel B: Mother } \\
\hline Maternal job loss & $\begin{array}{l}-1.66 \\
(1.49)\end{array}$ & $\begin{array}{l}-0.08 \\
(0.22)\end{array}$ & $\begin{array}{l}-\mathbf{0 . 5 2 *} \\
(0.29)\end{array}$ & $\begin{array}{l}-0.23 \\
(0.23)\end{array}$ & $\begin{array}{c}\mathbf{- 1 . 1 0} * * \\
(0.44)\end{array}$ & $\begin{array}{c}0.05 \\
(0.25)\end{array}$ & $\begin{array}{l}-\mathbf{- 0 . 4 5 \#} \\
(0.30)\end{array}$ & $\begin{array}{l}-0.02 \\
(0.24)\end{array}$ \\
\hline No. of observations & 213 & 882 & 534 & 561 & 362 & 733 & 685 & 410 \\
\hline \multicolumn{9}{|c|}{ Dependent variable: Weight-for-age $z$-score $(\mathrm{WAZ}(t))$} \\
\hline & Age $0-6$ & $\begin{array}{l}\text { Age } \\
6-18\end{array}$ & Boy & Girl & $\begin{array}{l}\text { HH income } \\
\text { below 30th } \\
\text { percentile }\end{array}$ & $\begin{array}{c}\text { HH } \\
\text { income } \\
\text { above } \\
\text { 30th } \\
\text { percentile }\end{array}$ & $\begin{array}{c}\text { No. of } \\
\text { adults } \leqslant \\
2\end{array}$ & $\begin{array}{c}\text { No. of } \\
\text { adults > } \\
\quad 2\end{array}$ \\
\hline & \multicolumn{8}{|c|}{ Panel C: Father } \\
\hline Paternal job loss & $\begin{array}{l}-1.89 \\
(1.44)\end{array}$ & $\begin{array}{c}\mathbf{- 0 . 3 9 * *} \\
(0.16)\end{array}$ & $\begin{array}{l}-\mathbf{0 . 4 0 *} \\
(0.23)\end{array}$ & $\begin{array}{l}-\mathbf{0 . 3 7 *} \\
(0.19)\end{array}$ & $\begin{array}{c}\mathbf{- 0 . 6 4 \#} \\
(0.39)\end{array}$ & $\begin{array}{l}-0.27 \\
(0.22)\end{array}$ & $\begin{array}{l}\mathbf{- 0 . 2 7 \#} \\
(0.18)\end{array}$ & $\begin{array}{l}\mathbf{- 0 . 5 0 \#} \\
(0.33)\end{array}$ \\
\hline \multirow[t]{2}{*}{ No. of observations } & 208 & 896 & 533 & 571 & 334 & 770 & 701 & 403 \\
\hline & \multicolumn{8}{|c|}{ Panel D: Mother } \\
\hline Maternal job loss & $\begin{array}{l}-0.60 \\
(1.22)\end{array}$ & $\begin{array}{l}-0.07 \\
(0.21)\end{array}$ & $\begin{array}{l}-\mathbf{- 0 . 3 6 \#} \\
(0.23)\end{array}$ & $\begin{array}{l}-0.15 \\
(0.24)\end{array}$ & $\begin{array}{c}\mathbf{- 1 . 2 2} * * * \\
(0.37)\end{array}$ & $\begin{array}{c}0.06 \\
(0.23)\end{array}$ & $\begin{array}{l}-\mathbf{- 0 . 4 5 *} \\
(0.23)\end{array}$ & $\begin{array}{c}0.08 \\
(0.27)\end{array}$ \\
\hline No. of observations & 213 & 882 & 534 & 561 & 362 & 733 & 685 & 410 \\
\hline
\end{tabular}

\section{Note:}

a) Standard errors in parentheses; \# $p<0.15, * p<0.10, * * p<0.05$, *** $p<0.01$.

b) Each regression included indicators for household income below the 30th percentile, household income above the 70th percentile, and whether household head is the father; numbers of children and adults; child's age; indicators for whether the child has health insurance and is a student; and year dummies.

c) For Panels A and C, other regressors included father's age, education, height and BMI, and an indicator for the presence of mother in the household.

d) For Panels B and D, other regressors included mother's age, education, height, and BMI, and an indicator for the presence of father in the household., 
Table 7. Parental Job Loss and Income Change (in 1000s of yuan of year 2006)

(OLS estimation controlling for $X_{t}$ )

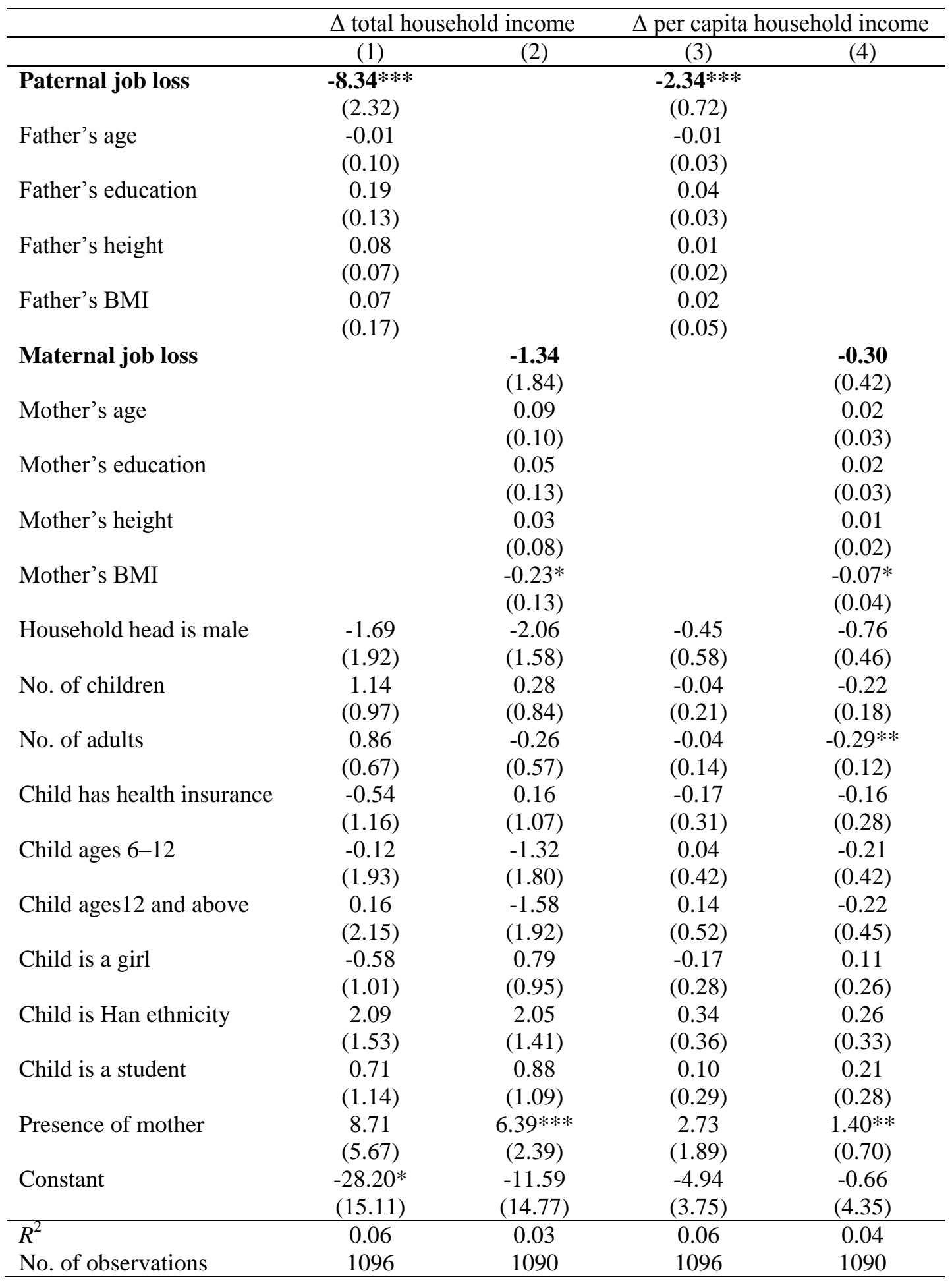

Note: Robust standard errors in parentheses; * $p<0.10, * * p<0.05$, *** $p<0.01$; other regressors included regional dummies and year dummies. 
Table 8. Parental Job Loss and Child Average Daily Nutrient Intake

(OLS controlling for $X_{t-1}$ )

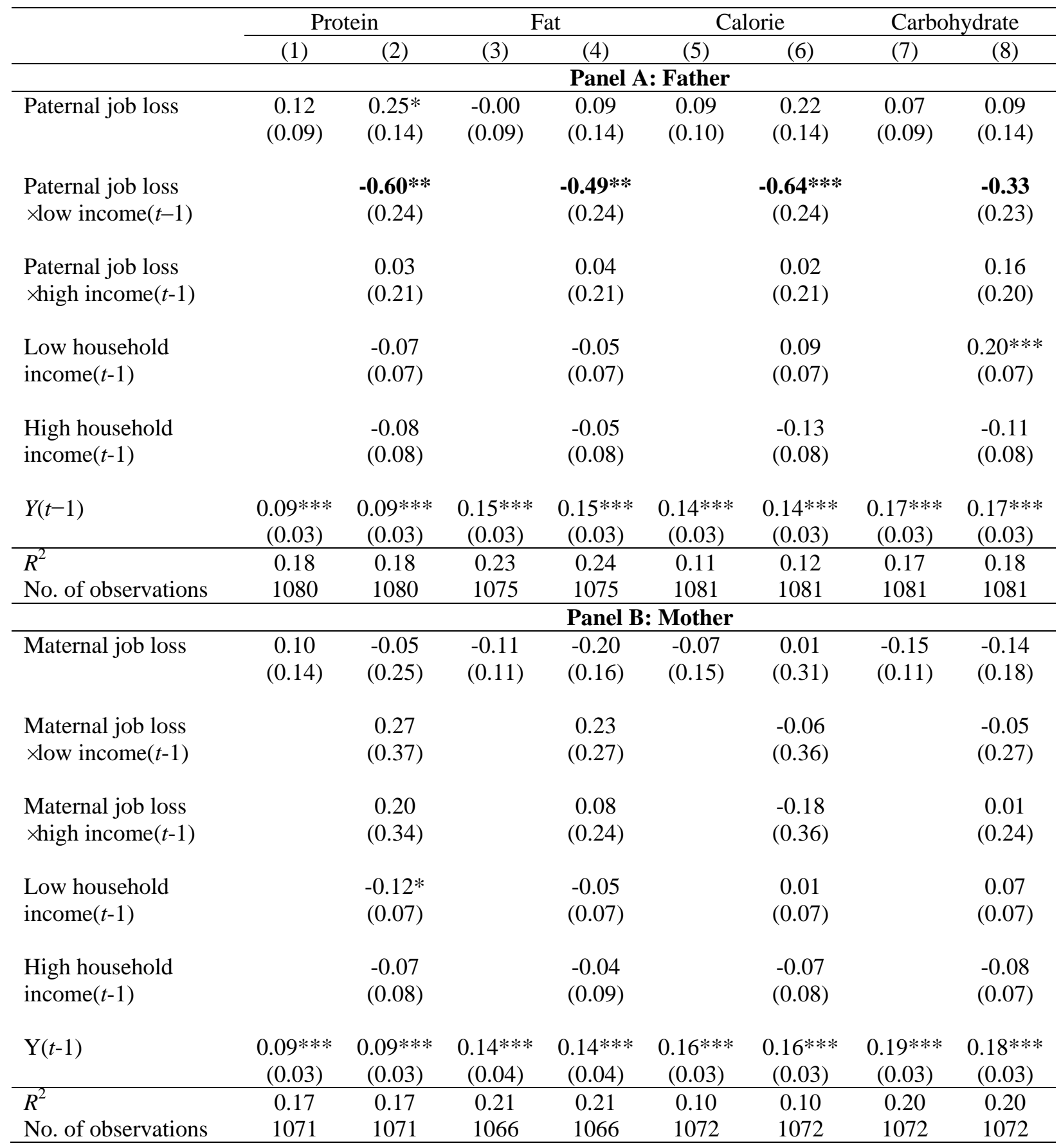

Note:

a) Robust standard errors in parentheses; * $p<0.10$, ** $p<0.05$, *** $p<0.01$.

b) The dependent variables have been standardized using sample mean and sample standard deviation for each age and gender group.

c) Each regression included indicators for whether household head is the father; number of children and adults; child's age; indicators for whether the child has health insurance, is a girl, is Han, and is a student; regional dummies; and year dummies.

d) For Panel A, other regressors included father's age, education, and BMI, and the presence of the mother in the household.

e) For Panel B, other regressors included mother's age, education, and BMI, and the presence of the father in the household. 
Table 9. Parental Job Loss and Child Health Care Use (Probit Estimation Controlling for $X_{t-1}$ )

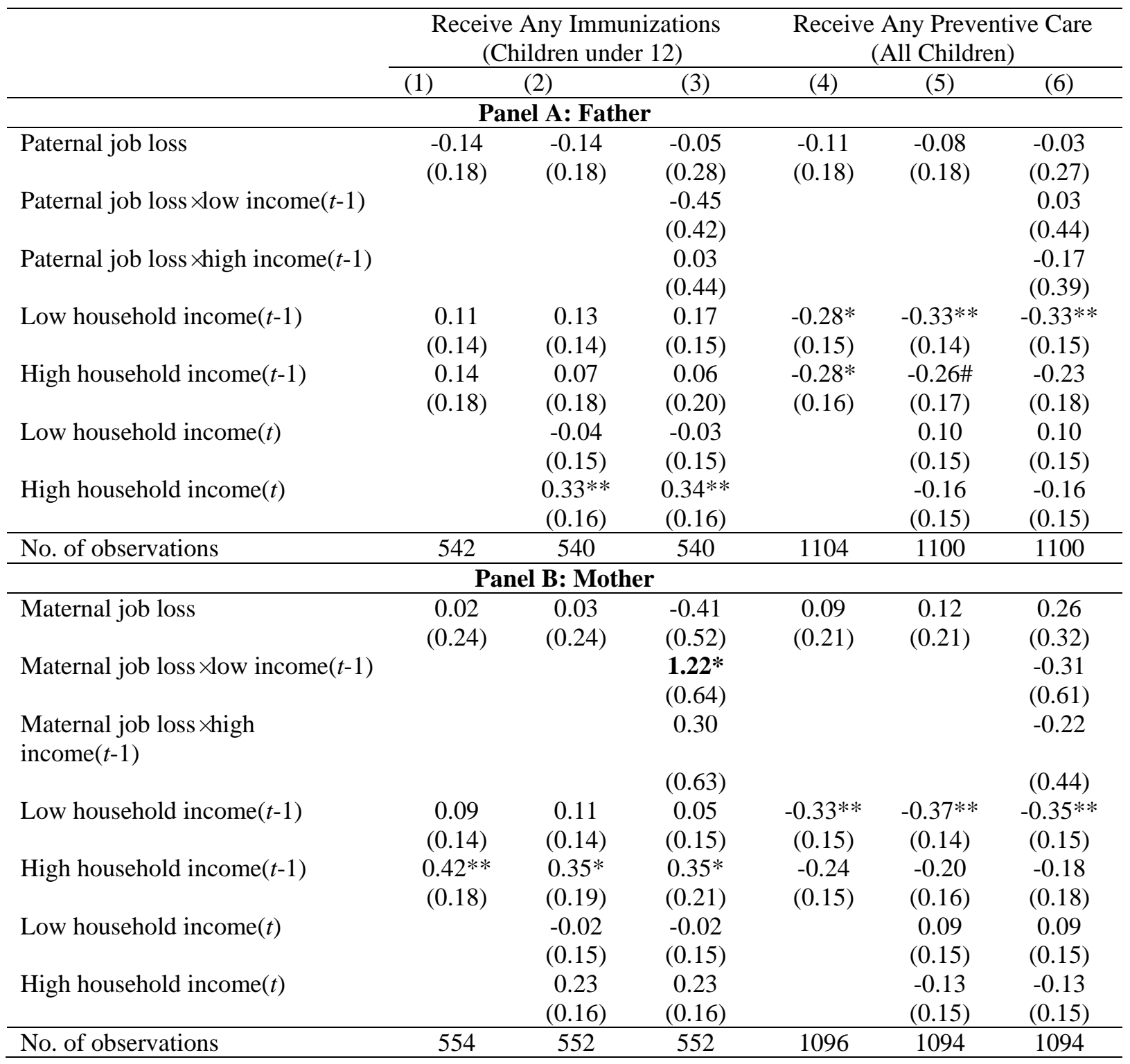

Note:

a) Coefficients are reported. Robust standard errors in parentheses; * $p<0.10$, $* * p<0.05$, *** $p<0.01$.

b) Each regression included indicators for whether household head is the father; numbers of children and adults; child's age; indicators for whether the child has health insurance, is a girl, is Han, and is a student; regional dummies; and year dummies.

c) For Panel A, other regressors included father's age, education, and BMI, and the presence of the mother in the household.

d) For Panel B, other regressors included mother's age, education, and BMI, and the presence of the father in the household. 


\section{Table 10. Parental Job Loss and Parental Time Allocation (Probit Estimation controlling for $X_{t}$ )}

\begin{tabular}{|c|c|c|c|}
\hline & $\begin{array}{l}\text { Take care of } \\
\text { children age } 6 \\
\text { and less }\end{array}$ & $\begin{array}{l}\text { Buy food for } \\
\text { household }\end{array}$ & $\begin{array}{c}\text { Prepare and } \\
\text { cook food }\end{array}$ \\
\hline & $(1)$ & $(2)$ & (3) \\
\hline \multicolumn{4}{|c|}{ Panel A: Father } \\
\hline Paternal job loss & $\begin{array}{c}0.07 \\
(0.31)\end{array}$ & $\begin{array}{l}-0.18 \\
(0.14)\end{array}$ & $\begin{array}{l}-0.08 \\
(0.15)\end{array}$ \\
\hline Low household income $(t-1)$ & $\begin{array}{c}-0.38 * \\
(0.23)\end{array}$ & $\begin{array}{c}0.12 \\
(0.09)\end{array}$ & $\begin{array}{c}0.30 * * * \\
(0.10)\end{array}$ \\
\hline High household income $(t-1)$ & $\begin{array}{c}-0.69 * * * \\
(0.22)\end{array}$ & $\begin{array}{c}0.01 \\
(0.10)\end{array}$ & $\begin{array}{l}-0.17 \# \\
(0.11)\end{array}$ \\
\hline Low household income $(t)$ & $\begin{array}{c}0.10 \\
(0.20)\end{array}$ & $\begin{array}{l}-0.01 \\
(0.09)\end{array}$ & $\begin{array}{c}-0.18 * \\
(0.10)\end{array}$ \\
\hline High household income $(t)$ & $\begin{array}{l}-0.19 \\
(0.23)\end{array}$ & $\begin{array}{l}-0.05 \\
(0.10)\end{array}$ & $\begin{array}{c}-0.23^{* *} \\
(0.10) \\
\end{array}$ \\
\hline No. of observations & 363 & 1300 & 1275 \\
\hline \multicolumn{4}{|c|}{ Panel B: Mother } \\
\hline Maternal job loss & $\begin{array}{c}\text { 0.56\# } \\
(0.36)\end{array}$ & $\begin{array}{c}\text { 0.38*** } \\
(0.17)\end{array}$ & $\begin{array}{c}\mathbf{0 . 0 7} \\
(0.18)\end{array}$ \\
\hline Low household income $(t-1)$ & $\begin{array}{c}0.90 * * \\
(0.37)\end{array}$ & $\begin{array}{c}0.07 \\
(0.10)\end{array}$ & $\begin{array}{c}0.07 \\
(0.12)\end{array}$ \\
\hline High household income $(t-1)$ & $\begin{array}{c}0.01 \\
(0.25)\end{array}$ & $\begin{array}{c}0.06 \\
(0.11)\end{array}$ & $\begin{array}{c}0.24 * * \\
(0.12)\end{array}$ \\
\hline Low household income $(t)$ & $\begin{array}{c}0.20 \\
(0.30)\end{array}$ & $\begin{array}{c}-0.43 * * * \\
(0.10)\end{array}$ & $\begin{array}{c}0.17 \\
(0.12)\end{array}$ \\
\hline High household income $(t)$ & $\begin{array}{l}-0.23 \\
(0.29) \\
\end{array}$ & $\begin{array}{l}-0.10 \\
(0.11)\end{array}$ & $\begin{array}{l}-0.01 \\
(0.12) \\
\end{array}$ \\
\hline No. of observations & 397 & 1332 & 1327 \\
\hline
\end{tabular}

\section{Note:}

a) Coefficients are reported.

b) Robust standard errors in parentheses; \# $p<0.15,{ }^{*} p<0.10, * * p<0.05, * * * p<0.01$.

c) Each regression included indicators whether household head is the father; numbers of children and adults; children's average age; percentages of girls and students in the household; regional dummies; and year dummies.

d) For Panel A, other regressors included father's age, education, and BMI, and the presence of the mother in the household.

e) For Panel B, other regressors included mother's age, education, and BMI, and the presence of the father in the household. 
Table 11. Parental Job Loss and Smoking Behavior of Family Members (Probit Estimation controlling for $X_{t}$ )

\begin{tabular}{|c|c|c|c|c|}
\hline & \multicolumn{2}{|c|}{$\begin{array}{c}\text { Children Age } \geqslant 12 \text { and } \\
\text { Smoke }\end{array}$} & \multicolumn{2}{|c|}{ Father Smokes } \\
\hline & Coef. & $\begin{array}{c}\text { Marginal } \\
\text { Effect }\end{array}$ & Coef. & $\begin{array}{c}\text { Marginal } \\
\text { Effect }\end{array}$ \\
\hline & $(1)$ & $(2)$ & (3) & (4) \\
\hline \multicolumn{5}{|c|}{ Panel A: Father } \\
\hline Paternal job loss & $\begin{array}{c}\mathbf{1 . 0 5} * * \\
(0.45)\end{array}$ & 0.0013 & $\begin{array}{c}\mathbf{0 . 2 8}^{* * *} \\
(0.13)\end{array}$ & 0.09 \\
\hline Low household income $(t-1)$ & $\begin{array}{c}0.96 \\
(0.65)\end{array}$ & & $\begin{array}{c}0.14 \\
(0.09)\end{array}$ & \\
\hline High household income $(t-1)$ & & & $\begin{array}{l}-0.07 \\
(0.10)\end{array}$ & \\
\hline Low household income $(t)$ & $\begin{array}{l}0.001 \\
(0.38)\end{array}$ & & $\begin{array}{l}-0.08 \\
(0.09)\end{array}$ & \\
\hline High household income $(t)$ & $\begin{array}{c}0.54 \\
(0.44) \\
\end{array}$ & & $\begin{array}{l}-0.08 \\
(0.09)\end{array}$ & \\
\hline No. of obs. & 618 & & 1443 & \\
\hline & Children & $\geqslant 12$ and & Motl & nokes \\
\hline & Panel B: & & & \\
\hline Maternal job loss & $\begin{array}{c}0.59 \\
(0.55)\end{array}$ & & $\begin{array}{c}0.51 \\
(0.42)\end{array}$ & \\
\hline Low household income $(t-1)$ & $\begin{array}{c}0.28 \\
(0.39)\end{array}$ & & $\begin{array}{l}-0.34 \\
(0.26)\end{array}$ & \\
\hline High household income $(t-1)$ & & & $\begin{array}{c}0.42 \\
(0.28)\end{array}$ & \\
\hline Low household income $(t)$ & $\begin{array}{l}-0.004 \\
(0.44)\end{array}$ & & $\begin{array}{c}0.15 \\
(0.26)\end{array}$ & \\
\hline High household income $(t)$ & $\begin{array}{l}-0.10 \\
(0.33)\end{array}$ & & $\begin{array}{c}0.33 \\
(0.28)\end{array}$ & \\
\hline No. of obs. & 613 & & 748 & \\
\hline
\end{tabular}

\section{Note:}

a) Robust standard errors in parentheses; * $p<0.10$, ** $p<0.05$, *** $p<0.01$.

b) Each regression included indicators whether household head is the father; numbers of children and adults; children's average age; percentages of girls and students in the household; regional dummies; and year dummies.

c) For Panel A, other regressors included father's age, education, and BMI, and the presence of the mother in the household.

d) For Panel B, other regressors included mother's age, education, and BMI, and the presence of the father in the household. 


\section{Appendix}

Table A1. Summary Statistics

\begin{tabular}{|c|c|c|c|c|c|c|}
\hline & & Full sample & & $\begin{array}{l}\text { With lost- } \\
\text { job } \\
\text { parents } \\
247 \text { obs. }\end{array}$ & $\begin{array}{c}\text { No lost- } \\
\text { job } \\
\text { parents } \\
1882 \text { obs. }\end{array}$ & \\
\hline \multirow[t]{2}{*}{ Variable } & Obs. & Mean & Std. Dev. & Mean & Mean & \\
\hline & (1) & $(2)$ & (3) & (4) & (5) & (6) \\
\hline \multicolumn{7}{|l|}{ Parental job loss } \\
\hline Mother lost job & 1641 & 0.061 & 0.239 & & & \\
\hline Father lost job & 1829 & 0.101 & 0.302 & & & \\
\hline Only father lost job & 2129 & 0.069 & 0.254 & & & \\
\hline Only mother lost job & 2129 & 0.029 & 0.168 & & & \\
\hline Both parents lost job & 2129 & 0.018 & 0.132 & & & \\
\hline Duration of maternal job loss & 1432 & 0.095 & 0.354 & & & \\
\hline Duration of paternal job loss & 1579 & 0.184 & 0.507 & & & \\
\hline \multicolumn{7}{|l|}{ Child health status } \\
\hline Height-for-age $z$-score & 2129 & -0.61 & 1.35 & -0.59 & -0.62 & \\
\hline Weight-for-age $z$-score & 2129 & -0.20 & 1.14 & -0.22 & -0.19 & \\
\hline \multicolumn{7}{|l|}{ Child characteristics } \\
\hline Child daily protein intake (g) & 2089 & 59.08 & 23.08 & 56.07 & 59.48 & $* *$ \\
\hline Child daily fat intake (g) & 2083 & 62.55 & 36.82 & 62.87 & 62.50 & \\
\hline Child daily calorie intake (kcal) & 2089 & 1939.45 & 677.76 & 1833.64 & 1953.45 & $* * *$ \\
\hline Child daily carbohydrate intake (g) & 2088 & 283.02 & 108.56 & 260.82 & 285.95 & $* * *$ \\
\hline Receive any immunization ${ }^{\mathrm{a}}$ & 1319 & 0.59 & 0.49 & 0.66 & 0.57 & $* *$ \\
\hline Receive any preventive care ${ }^{\mathrm{b}}$ & 2129 & 0.07 & 0.25 & 0.06 & 0.07 & \\
\hline Smoker (for children age $\geqslant 12$ ) $^{\mathrm{c}}$ & 874 & 0.02 & 0.14 & 0.00 & 0.02 & \\
\hline Child has health insurance & 2129 & 0.30 & 0.46 & 0.29 & 0.30 & \\
\hline Child age & 2129 & 10.68 & 4.20 & 9.65 & 10.82 & $* * *$ \\
\hline Child is a girl & 2129 & 0.48 & 0.50 & 0.45 & 0.48 & \\
\hline Child is Han & 2121 & 0.84 & 0.37 & 0.86 & 0.84 & \\
\hline Child is a student & 2129 & 0.71 & 0.45 & 0.69 & 0.72 & \\
\hline \multicolumn{7}{|l|}{ Household characteristics } \\
\hline Total gross household income (k) & 2126 & 16.15 & 13.09 & 18.80 & 15.80 & $* * *$ \\
\hline Household income per capita (k) & 2126 & 4.04 & 3.49 & 4.36 & 4.00 & \\
\hline Household head is male & 2129 & 0.88 & 0.33 & 0.85 & 0.88 & \\
\hline No. of children & 2129 & 1.59 & 0.72 & 1.66 & 1.58 & \\
\hline No. of adults & 2126 & 2.63 & 1.01 & 2.80 & 2.61 & $* * *$ \\
\hline
\end{tabular}


Table A1. Summary Statistics (Continued)

\begin{tabular}{|c|c|c|c|c|c|c|}
\hline & & Full sample & & $\begin{array}{l}\text { With lost- } \\
\text { job } \\
\text { parents } \\
247 \text { obs. }\end{array}$ & $\begin{array}{c}\text { No lost- } \\
\text { job } \\
\text { parents } \\
1882 \text { obs. }\end{array}$ & \\
\hline \multirow[t]{2}{*}{ Variable } & Obs. & Mean & Std. Dev. & Mean & Mean & \\
\hline & (1) & $(2)$ & (3) & (4) & (5) & (6) \\
\hline \multicolumn{7}{|l|}{ Father characteristics } \\
\hline Father's age & 2047 & 38.80 & 6.10 & 37.11 & 39.03 & $* * *$ \\
\hline Father's education & 2013 & 8.63 & 3.54 & 8.52 & 8.65 & \\
\hline Father's height (cm) & 1837 & 166.14 & 6.90 & 165.80 & 166.18 & \\
\hline Father's BMI & 1837 & 22.46 & 2.82 & 22.37 & 22.47 & \\
\hline Father smokes & 1901 & 0.70 & 0.46 & 0.75 & 0.70 & * \\
\hline $\begin{array}{l}\text { Father takes care of children age } 6 \\
\text { and less }{ }^{\text {d }}\end{array}$ & 564 & 0.42 & 0.49 & 0.40 & 0.42 & \\
\hline Father buys food for household ${ }^{\mathrm{e}}$ & 1995 & 0.47 & 0.50 & 0.44 & 0.47 & \\
\hline Father cooks food for household ${ }^{e}$ & 1946 & 0.37 & 0.48 & 0.27 & 0.39 & $* * *$ \\
\hline Father annual wage income (k) & 1295 & 5.04 & 5.44 & 4.85 & 5.08 & \\
\hline Presence of father in household & 2129 & 0.96 & 0.19 & 0.98 & 0.96 & \\
\hline \multicolumn{7}{|l|}{ Mother characteristics } \\
\hline Mother's age & 2092 & 36.85 & 5.80 & 34.99 & 37.09 & $* * *$ \\
\hline Mother's education & 2045 & 7.34 & 4.01 & 7.38 & 7.33 & \\
\hline Mother's height (cm) & 2023 & 155.13 & 6.10 & 155.55 & 155.08 & \\
\hline Mother's BMI & 2023 & 22.63 & 2.99 & 22.90 & 22.59 & \\
\hline Mother smokes & 2031 & 0.01 & 0.10 & 0.00 & 0.01 & \\
\hline $\begin{array}{l}\text { Mother takes care of kids age } 6 \text { and } \\
\text { less }{ }^{\mathrm{d}}\end{array}$ & 639 & 0.74 & 0.44 & 0.75 & 0.73 & \\
\hline Mother buys food for household ${ }^{\mathrm{e}}$ & 2079 & 0.68 & 0.47 & 0.67 & 0.68 & \\
\hline Mother cooks food for household ${ }^{\mathrm{e}}$ & 2063 & 0.86 & 0.35 & 0.81 & 0.87 & $* *$ \\
\hline Mother annual wage income (k) & 1043 & 4.10 & 4.73 & 3.70 & 4.16 & \\
\hline Presence of mother in household & 2129 & 0.98 & 0.13 & 0.98 & 0.98 & \\
\hline \multicolumn{7}{|l|}{ Instrumental variables } \\
\hline County-level layoff rate & 2129 & 0.10 & 0.07 & 0.13 & 0.09 & $* * *$ \\
\hline $\begin{array}{l}\text { Both parents worked in public } \\
\text { institutions }\end{array}$ & 2129 & 0.27 & 0.45 & 0.16 & 0.29 & $* * *$ \\
\hline $\begin{array}{l}\text { Both parents worked in SOE or } \\
\text { collective enterprises }\end{array}$ & 2129 & 0.40 & 0.49 & 0.42 & 0.40 & \\
\hline Open trade area in community & 2129 & 0.54 & 0.50 & 0.60 & 0.53 & $* *$ \\
\hline $\begin{array}{l}\text { No. of private enterprises in } \\
\text { community }\end{array}$ & 2064 & 15.37 & 30.22 & 20.92 & 14.65 & $* *$ \\
\hline
\end{tabular}

Note: Column (6) indicates if column (4) and column (5) are significantly different: $* p<0.10$, $* * p<0.05, * * * p<0.01$. 
Table A2. Robustness Check - Using Different Measures of Parental Job Loss (Fixed-Effects Estimation controlling for $X_{t-1}$ )

\begin{tabular}{|c|c|c|c|c|}
\hline & \multicolumn{2}{|c|}{$\begin{array}{c}\text { Height-for-age } z \text {-score } \\
\text { HAZ }(t)\end{array}$} & \multicolumn{2}{|c|}{$\begin{array}{c}\text { Weight-for-age } z \text {-score } \\
\text { WAZ }(t)\end{array}$} \\
\hline & (1) & (2) & (3) & (4) \\
\hline Control of $Y(t-1)$ & No & Yes & No & Yes \\
\hline \multicolumn{5}{|c|}{ Panel A: Father } \\
\hline $\begin{array}{l}\text { Main Measure } \\
\text { No. of observations }\end{array}$ & $\begin{array}{c}-\mathbf{- 0 . 3 3} * * \\
(0.13) \\
1104\end{array}$ & $\begin{array}{c}\mathbf{- 0 . 3 4 * *} \\
(0.13) \\
1104\end{array}$ & $\begin{array}{c}\mathbf{- 0 . 3 8 * *} \\
(0.15) \\
1104\end{array}$ & $\begin{array}{c}\mathbf{- 0 . 3 4 * *} \\
(0.15) \\
1104\end{array}$ \\
\hline $\begin{array}{l}\text { Alternative Measure } 1 \\
\text { No. of observations }\end{array}$ & $\begin{array}{c}\mathbf{- 0 . 2 4} * * \\
(0.11) \\
1162\end{array}$ & $\begin{array}{c}\mathbf{- 0 . 2 4} * * \\
(0.11) \\
1162\end{array}$ & $\begin{array}{c}-\mathbf{- 0 . 2 3 *} \\
(0.13) \\
1162\end{array}$ & $\begin{array}{c}-0.20 \\
(0.12) \\
1162\end{array}$ \\
\hline $\begin{array}{l}\text { Alternative Measure } 2 \\
\text { No. of observations }\end{array}$ & $\begin{array}{c}\mathbf{- 0 . 2 3 *} \\
(0.12) \\
1214\end{array}$ & $\begin{array}{c}\mathbf{- 0 . 2 5} * * \\
(0.12) \\
1214\end{array}$ & $\begin{array}{c}\mathbf{- 0 . 3 1} * * \\
(0.14) \\
1214\end{array}$ & $\begin{array}{c}\mathbf{- 0 . 2 9} * * \\
(0.13) \\
1214\end{array}$ \\
\hline $\begin{array}{l}\text { Alternative Measure } 3 \\
\text { No. of observations }\end{array}$ & $\begin{array}{c}\mathbf{- 0 . 2 0 *} \\
(0.10) \\
1280\end{array}$ & $\begin{array}{c}\mathbf{- 0 . 2 0} * * * \\
(0.10) \\
1280\end{array}$ & $\begin{array}{c}-0.04 \\
(0.13) \\
1280\end{array}$ & $\begin{array}{c}-0.05 \\
(0.12) \\
1280\end{array}$ \\
\hline
\end{tabular}

\begin{tabular}{lcccc}
\hline \multicolumn{5}{c}{ Panel B: Mother } \\
Main Measure & -0.28 & -0.26 & -0.17 & -0.21 \\
& $(0.18)$ & $(0.18)$ & $(0.17)$ & $(0.16)$ \\
No. of observations & 1096 & 1096 & 1096 & 1096 \\
\hline Alternative Measure 1 & -0.01 & -0.00 & 0.03 & -0.01 \\
& $(0.12)$ & $(0.12)$ & $(0.12)$ & $(0.12)$ \\
No. of observations & 1210 & 1210 & 1210 & 1210 \\
\hline Alternative Measure 2 & -0.20 & -0.18 & -0.12 & -0.13 \\
& $(0.16)$ & $(0.16)$ & $(0.15)$ & $(0.14)$ \\
No. of observations & 1198 & 1198 & 1198 & 1198 \\
\hline Alternative Measure 3 & & & & \\
& -0.00 & 0.01 & 0.09 & 0.06 \\
No. of observations & $(0.11)$ & $(0.11)$ & $(0.11)$ & $(0.10)$ \\
\hline
\end{tabular}

Note:

a) Standard errors in parentheses; * $p<0.10$, ** $p<0.05$, *** $p<0.01$.

b) Each regression includes indicators for household income below the 30th percentile, household income above the 70th percentile, and whether household head is the father; numbers of children and adults; child's age; indicators for whether the child has health insurance and is a student; and year dummies.

c) For Panel A, other regressors include father's age, education, height, and BMI, and an indicator for the presence of mother in the household.

d) For Panel B, other regressors include mother's age, education, height, and BMI, and an indicator for the presence of father in the household. 
Table A3. Robustness Check - IV Estimation of the Effect of Parental Job Loss on Child Health

(Controlling for $Y_{t-1}$ and $\left.X_{t-1}\right)$

\begin{tabular}{lcc}
\hline & \multicolumn{2}{c}{ Fixed Effect + IV } \\
& \multicolumn{2}{c}{ (LIML, robust to weak instruments) } \\
\cline { 2 - 3 } & Height-for-age & Weight-for-age \\
& $z$-score & Z-score \\
\hline & Panel A: Father & $(2)$ \\
\hline Paternal job loss & $\mathbf{- 0 . 6 8 *}$ & -0.22 \\
& $(0.39)$ & $(0.43)$ \\
\hline First-stage $F$-statistic & $F=8.28$ & $F=8.31$ \\
& $P<0.001$ & $P<0.001$ \\
Overidentification test & $P=0.540$ & $P=0.699$ \\
Endogeneity test & $P=0.288$ & $P=0.856$ \\
No. of observations & 1075 & 1075 \\
\hline & & \\
& & -1.12 \\
Maternal job loss & -1.15 & $(0.88)$ \\
\hline Weak instrument test & $(0.95)$ & $F=2.28$ \\
& $F=2.26$ & $P=0.046$ \\
Overidentification test & $P=0.049$ & $P=0.976$ \\
Endogeneity test & $P=0.359$ & $P=0.245$ \\
No. of observations & $P=0.306$ & 1075 \\
\hline
\end{tabular}

Note:

a) Instrumental variables include (1) indicators of whether both parents worked in public institutions, in state-owned enterprise, or collective enterprise before layoff; (2) county-level layoff rate excluding the child's parents; (3) indicator of whether there is an open trade area near this neighborhood (within two hours by bus); (4) number of private enterprises in this neighborhood.

b) Standard errors in parentheses; * $p<0.10, * * p<0.05, * * * p<0.01$. 
Table A4. Parental Job Loss and Marriage Instability (Controlling for $X_{t}$ )

\begin{tabular}{|c|c|c|}
\hline \multirow[t]{3}{*}{ Probit } & \multicolumn{2}{|c|}{ Divorce } \\
\hline & (1) & (2) \\
\hline & $\begin{array}{l}\text { From intact } \\
\text { family to single- } \\
\text { father family }\end{array}$ & $\begin{array}{l}\text { From intact } \\
\text { family to single- } \\
\text { mother family }\end{array}$ \\
\hline Paternal job loss & $\begin{array}{c}0.24 \\
(0.38)\end{array}$ & \\
\hline Maternal job loss & & $\begin{array}{c}0.38 \\
(0.38)\end{array}$ \\
\hline Low household income $(t-1)$ & $\begin{array}{c}0.06 \\
(0.38)\end{array}$ & - \\
\hline High household income $(t-1)$ & $\begin{array}{c}0.63 * * * \\
(0.19)\end{array}$ & $\begin{array}{c}0.08 \\
(0.33)\end{array}$ \\
\hline Low household income $(t)$ & $\begin{array}{c}0.85 * * * \\
(0.27)\end{array}$ & $\begin{array}{c}0.45 \\
(0.50)\end{array}$ \\
\hline $\operatorname{High}$ household income $(t)$ & $\begin{array}{l}-0.26 \\
(0.36)\end{array}$ & $\begin{array}{l}-0.58 * \\
(0.34)\end{array}$ \\
\hline No. of observations & 1331 & 1278 \\
\hline OLS & & \\
\hline Only father lost job & $\begin{array}{c}0.0078 \\
(0.0108)\end{array}$ & $\begin{array}{l}-0.0010 \\
(0.0020)\end{array}$ \\
\hline Only mother lost job & $\begin{array}{c}0.0008 \\
(0.0025)\end{array}$ & $\begin{array}{c}0.0115 \\
(0.0169)\end{array}$ \\
\hline Both parents lost job & $\begin{array}{c}0.0007 \\
(0.0029)\end{array}$ & $\begin{array}{l}-0.0026 \\
(0.0032)\end{array}$ \\
\hline Low household income $(t-1)$ & $\begin{array}{c}0.0014 \\
(0.0043)\end{array}$ & \\
\hline High household income $(t-1)$ & $\begin{array}{c}0.0004 \\
(0.0036)\end{array}$ & $\begin{array}{c}0.0007 \\
(0.0032)\end{array}$ \\
\hline Low household income $(t)$ & $\begin{array}{c}0.0040 \\
(0.0042)\end{array}$ & $\begin{array}{l}-0.0012 \\
(0.0035)\end{array}$ \\
\hline High household income $(t)$ & $\begin{array}{l}-0.0018 \\
(0.0035)\end{array}$ & $\begin{array}{l}-0.0024 \\
(0.0029)\end{array}$ \\
\hline No. of observations & 1425 & 1442 \\
\hline
\end{tabular}

Note:

a) Coefficients are reported.

b) Robust standard errors in parentheses; * $p<0.10$, ** $p<0.05$, *** $p<0.01$.

c) Probit estimation cannot be conducted for the second panel, because of the low mean values of both dependent variables and the key independent variable "both parents lost job". So we use linear probability models. In our sample, only $0.4 \%$ of families change from intact family to single-father family, and $0.2 \%$ from intact family to single-mother family. 